\title{
Identification of High Affinity Folate Binding Proteins in Human Erythrocyte Membranes
}

\author{
Asok C. Antony, R. Stephen Kincade, Rama S. Verma, and S. Ram Krishnan \\ Division of Hematology-Oncology, Department of Medicine, Indiana University School of Medicine, Indianapolis, Indiana 46223
}

\begin{abstract}
Mature human erythrocyte membranes contained specific, high affinity $\left(K_{d} 3.3 \times 10^{-11} \mathrm{M}\right)$ folate binding moieties. Folate binding was pH, time- and temperature-dependent, saturable, and was much greater for pteroylmonoglutamate and 5-methyltetrahydrofolate than 5-formyltetrahydrofolate and amethopterin. On detergent solubilization of membranes, two peaks of specific folate binding with $M_{r} \geq 200,000$ and 160,000 were identified on Sephacryl S-200 gel filtration chromatography in Triton X-100, and this corresponded to two similar peaks of immunoprecipitated material when solubilized iodinated membranes were probed with anti-human placental folate receptor antiserum. Age-dependent separation of erythrocytes by Stractan density gradients revealed a sevenfold greater folate binding capacity in membranes purified from younger compared with aged erythrocytes. Since this difference was not reflected in proportionately higher immunoreactive folate binding protein, (as determined by a specific radioimmunoassay for these proteins), or differences in affinity in younger than aged cells, these findings indicate that erythrocyte folate binding proteins become progressively nonfunctional at the onset of red cell aging.
\end{abstract}

\section{Introduction}

The intracellular role of folates as donors of one-carbon groups in enzyme reactions that lead to DNA synthesis has been well documented, and an adequate supply of folates must be assured each cell since folate deficiency leads to disordered DNA synthesis and consequent cell death (1). Therefore, specific mechanisms for cellular folate uptake and its retention could exist physiologically. This is most convincingly suggested in the developing human fetus, which concentrates and assures itself adequate folate stores even in the presence of maternal folate deficiency $(1,2)$. This suggests that a folate concentrating mechanism is mediated by the placenta, the organ that transfers nutrients between the maternal and fetal circulation. Based on these clinical observations, we identified, purified, and characterized a human placental particulate membraneassociated folate binding protein that had a high affinity for 5-methyltetrahydrofolate in the range for binding folates in serum (3). Although the hypothesis that these placental folate

Address reprint requests to Dr. Antony, 541 Clinical Drive, Room 379, Indianapolis, IN 46223.

Received for publication 3 October 1986 and in revised form 13 March 1987.

J. Clin. Invest.

(C) The American Society for Clinical Investigation, Inc.

0021-9738/87/09/0711/13 $\$ 2.00$

Volume 80, September 1987, 711-723 binding proteins are involved in transplacental transport of folates in humans cannot be further tested in vivo, taken together, the clinical observations and experimental studies are supporting (albeit indirect) evidence that these proteins may act as physiologically relevant specific folate receptors in human placenta (4). At the cellular level, it has long been speculated that other particulate folate binding proteins ( $P$ FBPs) ${ }^{1}$ in a variety of human tissues (5-7) have some important role in folate metabolism, either as intracellular folate storage proteins or as carriers for the transmembrane transport of folates. However, only in a human nasopharyngeal carcinoma cell line in culture, has there been direct evidence for a specific transport role for such externally oriented high affinity P-FBPs in human cells (8). To identify whether folate receptors are unique to malignant human cells, it is necessary to investigate their presence in other normal human cells that have been shown to transport folate intracellularly. Earlier, antiserum to purified placental folate receptors (PFR) identified moieties with shared antigenic determinants in mature human erythrocytes (3). Since human erythrocytes can take up folates (9-11) and retain them intracellularly (1), these cells seemed a logical choice to investigate for the presence of $\mathbf{P}$ FBPs. Such studies have not been performed with these or other homogeneous plasma membranes from normal human cells. A novel stable folate analogue, (a histamine derivative of folic acid), with a specific activity 40-50-fold higher than any previously available radiolabeled folate, allowed for the identification of proteins on erythrocyte membranes that have folate binding characteristics that are similar to that reported in human KB cells (12). Solubilization of radioligand-bound as well as radioiodinated membranes released folate binding proteins and iodinated proteins, respectively, that were specifcally immunoprecipitated by anti-PFR antiserum. Further quantitation of these solubilized moieties by a specific, sensitive radioimmunoassay (RIA) to the PFR and correlation with the particulate membrane ligand binding assay allowed for a study of the age-related changes of folate binding proteins in young and old erythrocytes.

\section{Methods}

A histamine derivative of folic acid, 1-carboxy-3-( $N$-(2-(4-imidazolyl)ethyl)carbamoyl)-1-pteroylaminopropane, was synthesized by $\mathrm{Du}$ pont/New England Nuclear, Boston, MA, and iodinated by the method of Hunter and Greenwood (13) using chloramine $T$ and carrier free ${ }^{125} \mathrm{I}$. The ${ }^{125} \mathrm{I}$-labeled derivative [ ${ }^{125} \mathrm{I}$-labeled PteGlu, (histamine

1. Abbreviations used in this paper: BSG, buffered saline glucose, LDH, lactic dehydrogenase; PEP, phosphoenolpyruvate; P-FBP, particulate folate binding proteins; PFR, placental folate receptor; PK, pyruvate kinase; PMSF, phenylmethylsulfonyl fluoride; PteGlu, pteroylmonoglutamic acid (folic acid); 2-ME, 2-mercaptoethanol; TEA, triethanolanine; TLC, thin-layer chromatography. 
derivative)], was $>99 \%$ pure and had $\sim 2,200 \mathrm{Ci} / \mathrm{mmol}$ sp act or $3,340 \mu \mathrm{Ci} / \mu \mathrm{g}\left(M_{\mathrm{r}} 659.6\right)$. Sodium iodide, carrier free, $14.2 \mathrm{mCi} / \mu \mathrm{g} \mathrm{sp}$ act of iodine was obtained from Amersham Corp. (Arlington Heights, IL). Pteroylglutamate (PteGlu, 99\% pure), $d, 1-5$-methyltetrahydrofolate (90\% pure), amethopterin (90\% pure) and 5-formyltetrahydrofolate (90\% pure), Sephacryl S-200, blue dextran, phenylmethylsulfonyl fluoride (PMSF), 2-mercaptoethanol (2-ME) Triton X-100, dimethylsulfoxide, monobasic and dibasic sodium phosphate and potassium phosphate, sodium deoxycholate, NP-40, the test kit for measuring total hemoglobin, arabinogalactan (Stractan), Amberlite MB-4B, triethanolamine (TEA), phosphoenolpyruvate (PEP), NADH, lactic dehydrogenase (LDH), and adenine dinucleotide phosphate, (ADP), were obtained from Sigma Chemical Company, St. Louis, MO. Beef lung heparin was from Upjohn Co., Kalamazoo, MI. IgG Sorb, a 10\% cell suspension of formalin-fixed Staphylococcus aureus cells bearing protein A was obtained from The Enzyme Center, Inc., Boston, MA. Iodogen (1,2,4,6-tetrachloro-3 $\alpha, 6 \alpha$-diphenylglycouril) was obtained from Pierce Chemical Co., Rockford, IL.

Determination of the purity and stability of ${ }^{125}$ I-labeled PteGlu (histamine derivative). Since a novel radiolabeled folate compound was used, it was necessary to determine its purity and stability under various experimental conditions used to identify folate binding sites on erythrocyte membranes. Analysis for purity was determined by high performance liquid chromatography (HPLC) and thin-layer chromatography (TLC); both techniques have been recently used to establish the purity of and purify folates (8). The HPLC apparatus (Waters Associates, Milford, MA) consisted of two model 510 pumps connected to a U6K injector ( $2 \mathrm{ml}$ capacity), a (Lambda-Max model 481 LC) spectrophotometer (set at 0.005 AUFS) connected to a model 1200 linear recorder (set at $30 \mathrm{~cm} / \mathrm{h}$ ) and a $3.9 \mathrm{~mm} \times 30 \mathrm{~cm} \mu$ Bondapak $\mathrm{C}_{18}$ stainless steel column. The column was run isocratically in $84 \%$ buffer A (5 mM Pic A, $10 \mathrm{mM} \mathrm{KH}_{2} \mathrm{PO}_{4}: \mathrm{H}_{3} \mathrm{PO}_{4}$, pH 5.5) and $16 \%$ buffer $B$ (acetonitrile). The column flow rate was $1 \mathrm{ml} / \mathrm{min}$ and $0.5-\mathrm{ml}$ fractions were collected and counted for radioactivity. Samples were routinely suspended in $250-\mu$ l column equilibration buffer before injection. Thin-layer chromatography analysis was performed by application of radiolabeled folate samples $(5 \mu \mathrm{l})$ to Avicel microcrystalline cellulose plates $(20 \times 20 \mathrm{~cm}, 250 \mu \mathrm{m}$, Analtech, Newark, DE) developed in $N$-propanol: $\mathrm{NH}_{4} \mathrm{OH}$ 7:3 at room temperature. The plates were subsequently dried and subjected to autoradiography using Kodak X-omat AR film and Cronex Lighting Plus intensifying screens at $-70^{\circ} \mathrm{C}$. Samples subjected to HPLC and TLC analyses were as follows: (a) commercially supplied ${ }^{125} \mathrm{I}$-labeled PteGlu (histamine derivative); (b) an aliquot of the peak fraction from sample $a$ after HPLC; (c) sample $b$ that was incubated for $2 \mathrm{~h}$ at $37^{\circ} \mathrm{C}$. (d) To determine if the peak fraction from HPLC (which corresponded to maximal absorbance at $\mathrm{A}_{280}$ as well as the maximum radioactivity) was authentic ${ }^{125}$ I-labeled PteGlu (histamine derivative), its specific binding to erythrocyte membranes was compared to an equivalent amount of unfractionated ${ }^{125} \mathrm{I}$-labeled PteGlu (histamine derivative); the radioactivity that was eluted by low pH (5.5) washes after binding of unfractionated or HPLC purified ${ }^{125}$ I-labeled PteGlu (histamine derivative) to erythrocyte membranes (see below), was also analyzed by TLC to determine if the eluted radioactivity corresponded to authentic ${ }^{125} \mathrm{I}$-labeled PteGlu (histamine derivative).

Preparation of purified erythrocyte membranes. Erythrocyte membranes were prepared from whole blood collected in heparin $(33 \mathrm{U} / \mathrm{ml})$ obtained from normal human volunteers (whose reticulocyte count was not $>1 \%$ ) and $99 \%$ of leukocytes were removed as previously described (3). After four centrifuge-wash cycles at $1,000 \mathrm{~g}$ for $10 \mathrm{~min}$ at $4^{\circ} \mathrm{C}$ with 10 vol $0.01 \mathrm{M}$ potassium phosphate $\left(\mathrm{KPO}_{4}\right)$, $\mathrm{pH} 7.5$ containing $0.15 \mathrm{M} \mathrm{NaCl}$ (phosphate-buffered saline, PBS) per wash cycle and aspiration of the supernatant with each wash, the pellets of packed cells were lysed by the method of Lieber and Steck (14). The lysis buffer contained $5 \mathrm{mM}$ sodium phosphate, $\mathrm{pH} 8,10 \mu \mathrm{M}$ magnesium sulfate $\left(\mathrm{MgSO}_{4}\right.$ ) and $20 \mu \mathrm{g} / \mathrm{ml}$ fresh PMSF (PMSF stock solution $200 \mathrm{mg} / \mathrm{ml}$ in dimethylsulfoxide), and the ratio of packed cells to lysis buffer was $1: 40$. The mixture was centrifuged at $30,000 \mathrm{~g}$ in a centrifuge (Beck- man J2-21 M, Beckman Instruments, Inc., Palo Alto, CA) at $4^{\circ} \mathrm{C}$ for $13 \mathrm{~min}$. After aspiration of the supernatant, the centrifuge-wash cycle was repeated four times. The erythrocyte membranes were then resuspended in a volume of lysis buffer that was equal to the original volume of packed cells. Each milliliter of washed erythrocyte membranes contained an average of $5 \mathrm{mg}$ protein as measured by the method of Lowry et al. (15); there was $<0.1 \mathrm{mg}$ of hemoglobin associated with each milliliter of membranes as determined by the cyanmethemoglobin method using Drabkins Reagents and a stable human hemoglobin standard (16). Glyceraldehyde 3-phosphate dehydrogenase accessibility assays $(14,17)$ were routinely performed to ensure that the membranes were not sealed either as right-side-out ghosts or inverted vesicles and confirmed $>90 \%$ accessibility to the enzyme.

Folate binding assay. Unless specified, all incubations were for $1 \mathrm{~h}$ at $37^{\circ} \mathrm{C}$. To determine the saturability and specificity of erythrocyte membrane folate binding, $1.3 \mathrm{ml}$ of a suspension of erythrocyte membranes were mixed with increasing concentrations of ${ }^{125} \mathrm{I}$-labeled PteGlu (histamine derivative) diluted in $2 \mathrm{ml}$ lysis buffer. After incubation, $3 \mathrm{ml}$ of ice-cold lysis buffer was added and the sample was centrifuged in Biovials (Beckman Instruments) at $30,000 \mathrm{~g}$ for $7 \mathrm{~min}$ at $4^{\circ} \mathrm{C}$. The supernatant was aspirated and the pellet was washed four times (10 vol/wash cycle) and counted for bound radioactivity in a Beckman gamma 5500 counter at $78 \%$ efficiency. For each level of radiolabeled ${ }^{125}$ I-labeled PteGlu (histamine derivative) used, simultaneous assays were performed containing a 1,000-fold excess of unlabeled PteGlu [in addition to ${ }^{125}$ I-labeled PteGlu (histamine derivative)] to determine the extent of nonspecific folate binding.

To determine the optimum $\mathrm{pH}$ for ligand binding, vials containing $1 \mathrm{ml}$ of erythrocyte membranes were centrifuged to sediment membranes. After aspiration of the supernatant, pellets were suspended with $25 \mathrm{fmol}{ }^{125}$ I-labeled PteGlu (histamine derivative) in a final volume of $1 \mathrm{ml}$ containing $10 \mu \mathrm{mol}$ sodium phosphate at $\mathrm{pH}$ ranging between 4.5 and 9.25 . (The $\mathrm{pH}$ was adjusted in stock solutions by adding $0.1 \mathrm{M}$ dibasic sodium phosphate to $0.1 \mathrm{M}$ monobasic sodium phosphate). After incubation, the pellets were washed with the same pH buffer four times. After determination of the amount of membrane-bound radioligand at varying $\mathrm{pH}$, the pellets were washed with 10 vol of lysis buffer ( $\mathrm{pH} 8$ ) for two cycles, (to uniformly neutralize the $\mathrm{pH}$ in membranes that were previously washed with various $\mathrm{pH}$ buffers), and mixed with $25 \mathrm{fmol}^{125} \mathrm{I}$-labeled PteGlu (histamine derivative) in $1 \mathrm{ml}$ lysis buffer ( $\mathrm{pH} \mathrm{8}$ ). After incubation, the pellets were washed with lysis buffer ( $\mathrm{pH} 8$ ) and counted for bound radioactivity. All folate binding assays were routinely performed in triplicate and the data are expressed as a mean of three experiments. There was $<5 \%$ deviation of folate binding from the mean for each set of assays. Erythrocyte membranes that were washed with lysis buffer pH 5.5 (to dissociate bound endogenous folate) were also assayed for the presence of endogeneous (bound) folate as previously described (8). The upper limits of sensitivity of this assay was $\mathbf{5 0}$ fmol folate (range $50 \mathrm{fmol}-5$ pmol) using ${ }^{125}$ I-labeled PteGlu (histamine derivative) as the radioligand. Membranes were prepared for this analysis as follows: $10 \mathrm{ml}$ of membranes that were first washed with lysis buffer $\mathrm{pH} 5.5$ as described above, were then resuspended in lysis buffer, $\mathrm{pH} 8$, and sedimented in the ultracentrifuge (see below). After addition of $1 \mathrm{ml}$ of "boiling" buffer $(160 \mathrm{mM}$ borate-KOH, $\mathrm{pH} 9.3$, containing $150 \mathrm{mM} \mathrm{NaCl}$ and 2 $\mu \mathrm{M}$ dithiothreitol) and boiling at $100^{\circ} \mathrm{C}$ for $30 \mathrm{~min}$, the membranes were sedimented again in the ultracentrifuge. The supernatant was subsequently analyzed for the presence of endogenous folate.

Molecular weight of erythrocyte folate binding proteins. Membranes purified from $20 \mathrm{ml}$ of packed cells were prewashed with $40 \mathrm{vol}$ of lysis buffer, pH 5.5, to remove endogenous folate (see above). After two 40-vol wash-cycles with lysis buffer, $\mathrm{pH} 8$, they were sedimented in a Beckman L8-55M ultracentrifuge (SW 55 rotor) at 55,000 rpm for 1 $\mathrm{h}$ at $4^{\circ} \mathrm{C}$. The supernatants were aspirated and the pellets resuspended in a final volume of $3 \mathrm{ml}$ in lysis buffer containing $2 \% \mathrm{NP}-40$ (vol/vol), $1 \%$ Triton X-100 (vol/vol) and $2 \mathrm{mg}$ PMSF. After incubation on a shaking platform for $24 \mathrm{~h}$ at $4^{\circ} \mathrm{C}$, the mixture was centrifuged at $55,000 \mathrm{rpm}$ for $30 \mathrm{~min}$, and the supernatant filtered through a $0.22-\mu \mathrm{m}$ 
filter (Millex-GV, Millipore Corp., Bedford, MA) to retain insoluble particulate material. The filtrate was incubated with $250 \mathrm{fmol}^{125} \mathrm{I}$-labeled PteGlu (histamine derivative) for $1 \mathrm{~h}$ at $37^{\circ} \mathrm{C}$, cooled to $4^{\circ} \mathrm{C}$, and applied to a $2.5 \times 30 \mathrm{~cm}$ Sephacryl S-200 gel filtration column that was equilibrated and eluted with $0.01 \mathrm{M} \mathrm{KPO}_{4}, \mathrm{pH} 7.5$, containing $1 \%$ Triton X-100 at $4{ }^{\circ} \mathrm{C}$. The column was calibrated with [methyl $-{ }^{14} \mathrm{C}$ ]methylated marker proteins (New England Nuclear) as previously described (18). Fractions of $2.75 \mathrm{ml}$ were collected and counted for radioactivity. Recovery of the applied radioactivity in eluted fractions was $>85 \%$. A duplicate sample was prepared as above except that during incubation with ${ }^{125} \mathrm{I}$-labeled PteGlu (histamine derivative) a 1,000-fold excess of unlabeled PteGlu was also added to the mixture to determine nonspecific ${ }^{125} \mathrm{I}$-labeled PteGlu (histamine derivative) binding.

Antigenic identity of erythrocyte FBPs. To determine if the solubilized erythrocyte FBPs were antigenically related to PFR (3), human PFR was purified to apparent homogeneity, (based on a single band on sodium dodecyl sulfate polyacrylamide gel electrophoresis), and antiserum to the purified protein was raised in rabbits as previously described (3). $1 \mathrm{ml}$ of erythrocyte membranes were iodinated by the method of Markwell and Fox (19) using $400 \mu \mathrm{g}$ Iodo-gen and $1 \mathrm{mCi}$ ${ }^{125}$ I Na. After transfer of the quenched reaction mixture to a $15-\mathrm{ml}$ Corex tube, the iodinated membranes were washed with 16 centrifuge-wash cycles with lysis buffer ( 30 vol per wash cycle). Incorporation of radioiodine into erythrocyte membranes ranged between 55 and $70 \%$ in five different experiments. The sample was solubilized with $2 \%$ Triton X-100 and 2\% NP-40 and subjected to gel filtration chromatography, as described above. $10 \mu \mathrm{l}$ of crude rabbit antiserum raised against the purified human PFR was added to $1.350 \mathrm{ml}$ of each gel filtration fraction. The mixture was incubated on a shaking platform for $16 \mathrm{~h}$ at $4^{\circ} \mathrm{C}$, following which $100 \mu \mathrm{l}$ IgG Sorb was added to each tube. After incubation for $30 \mathrm{~min}$ at $4^{\circ} \mathrm{C}$, the samples were centrifuged at $30,000 \mathrm{~g}$ for $60 \mathrm{~min}$ at $4^{\circ} \mathrm{C}$. The supernatants were aspirated and the pellets were washed with $30 \mathrm{vol}$ of lysis buffer for three cycles and counted for radioactivity. Simultaneous studies were performed on the second aliquot $(1.350 \mathrm{ml})$ of each eluted fraction using $10 \mu \mathrm{l}$ crude rabbit preimmune serum. Specific immunoprecipitation in each fraction was defined as the difference between total and nonspecific counts precipitated by immune anti-human PFR serum and by preimmune serum, respectively.

To determine if the moiety immunoprecipitated by anti-PFR serum was a folate binding protein, tubes containing $1 \mathrm{ml}$ of ghosts that were pretreated to remove endogenous folate, as described above, were incubated with $35 \mathrm{pM}^{125} \mathrm{I}$-labeled PteGlu (histamine derivative) in lysis buffer, $\mathrm{pH} 8$, for $1 \mathrm{~h}$ at $37^{\circ} \mathrm{C}$. After removal of unbound radioligand by four centrifuge-wash cycles, the pellets were counted for radioactivity. Each tube was subsequently solubilized with $1 \%$ deoxycholate (vol/vol) and 2\% Triton X-100 (vol/vol) in a final volume of $3 \mathrm{ml}$ at $4^{\circ} \mathrm{C}$ for $18 \mathrm{~h}$ on a shaking platform. The samples were then centrifuged at $30,000 \mathrm{~g}$ for $30 \mathrm{~min}$ at $4^{\circ} \mathrm{C}$ to sediment insoluble material. The supernatants $(2.9 \mathrm{ml})$ from each tube were subsequently incubated for $18 \mathrm{~h}$ at $4^{\circ} \mathrm{C}$ on a shaking platform with increasing concentrations of crude anti-human PFR serum diluted into a final volume of $100 \mu \mathrm{l}$ with crude rabbit preimmune serum. $1 \mathrm{ml}$ of $20 \%$ polyethylene glycol ( $w t / v o l$ ) was then added to each tube and the mixture incubated for 10 min at $4^{\circ} \mathrm{C}$. After centrifugation at $30,000 \mathrm{~g}$, for $1 \mathrm{~h}$ at $4^{\circ} \mathrm{C}$, the supernatants were aspirated and the pellets were counted for radioactivity. Simultaneous control studies were performed as described above except that increasing concentrations of preimmune serum were substituted for immune serum. Specific immunoprecipitation was determined as defined above.

Radioimmunoassay for placental folate receptors. PteGlu-Sepharose was prepared as previously described (3). $10 \mu \mathrm{l}$ of PFR was incubated with a 1:15 dilution of PteGlu-Sepharose in a final volume of 50 $\mu \mathrm{l}$ in $0.01 \mathrm{M} \mathrm{KPO}_{4}, \mathrm{pH} 7.5$, containing $1 \%$ Triton X-100 on a shaking platform at $4^{\circ} \mathrm{C}$ for $18 \mathrm{~h}$. The PteGlu-Sepharose with bound PFR was washed five times with $1.5 \mathrm{ml} 0.01 \mathrm{M} \mathrm{KPO}_{4}, \mathrm{pH} 7.5,(1.5 \mathrm{ml}$ per wash cycle) in a microcentrifuge (model 59A, Fisher Scientific, Pittsburgh, PA) at top speed for $2 \mathrm{~min}$ at $22^{\circ} \mathrm{C}$. The beads were resuspended in 1 $\mathrm{ml}$ of $0.01 \mathrm{M} \mathrm{KPO}_{4}, \mathrm{pH} 7.5$ and iodinated with $1 \mathrm{mCi}{ }^{125} \mathrm{I} \mathrm{Na}$ and $5 \mu \mathrm{g}$ Iodo-gen in a 20 -ml glass scintillation vial, as described (19). After incubation with the reaction mixture for $20 \mathrm{~min}$ at $22^{\circ} \mathrm{C}$ on a shaking platform, the contents were applied to a $0.5 \times 10 \mathrm{~cm}$ Econo-Column (Bio-Rad Laboratories, Richmond, CA). The retained beads were successively washed with 1 liter of $0.01 \mathrm{M} \mathrm{KPO}_{4}, \mathrm{pH} 7.5$, containing $1 \%$ Triton X-100 and $25 \mathrm{ml}$ of $0.001 \mathrm{M} \mathrm{KPO}_{4}, \mathrm{pH} 7.5$, containing $1 \%$ Triton X-100. The iodinated PFR that remained bound to PteGluSepharose was finally eluted with three successive batches of $500 \mu \mathrm{l} 0.2$ $M$ glacial acetic acid containing $1 \%$ Triton X-100 and the eluate was collected in its entirety. After $1 \mathrm{M} \mathrm{KPO}_{4}, \mathrm{pH} 7.5$, was added to the eluate to adjust the final concentration to $100 \mathrm{mM} \mathrm{KPO}_{4}$, the $\mathrm{pH}$ was adjusted to 7.5 by the addition of $1 \mathrm{~N} \mathrm{NaOH}$. The sample was subsequently analyzed by Sephacryl S-200 gel filtration (8), sucrose density gradient ultracentrifugation in the presence of detergent (18) (data not shown) and sodium dodecyl sulfate polyacrylamide gel electrophoresis of a detritonized sample (3) (Fig. $8 \mathrm{~A}$ ). Since all three techniques revealed a single major iodinated species corresponding to a $M_{\mathrm{r}}$ of 40,000 , the ${ }^{125}$ I-placental folate receptor $\left({ }^{125} \mathrm{I}\right.$-PFR) was therefore used as the radiolabeled antigen in the radioimmunoassay. Assuming a $50 \%$ recovery of non-denatured ${ }^{125} \mathrm{I}-\mathrm{PFR}$ that remained bound to PteGluSepharose, the specific activity of the iodinated receptor was $1.6 \mu \mathrm{Ci} / \mu \mathrm{g}$ protein. A final reaction mixture for the standard curve of $500 \mu \mathrm{l}$ contained $5 \mu \mathrm{mol} \mathrm{KPO}{ }_{4}, \mathrm{pH} 7.5,1 \%$ Triton X-100 (vol/vol), $0.2 \mu \mathrm{l}$ of crude rabbit antiserum to the placental folate receptor diluted in $20 \mu \mathrm{l}$ rabbit preimmune serum, increasing concentrations of purified placental folate receptor (stock solution $1 \mathrm{mg} / \mathrm{ml}$ in $0.01 \mathrm{M} \mathrm{KPO}_{4}, \mathrm{pH}$ 7.5, containing $1 \%$ Triton X-100) diluted in $0.01 \mathrm{M} \mathrm{KPO}_{4}, \mathrm{pH} 7.5$, containing $1 \%$ Triton $X-100$. After incubation for $18 \mathrm{~h}$ at $4^{\circ} \mathrm{C}$ on a shaking platform, $10,000 \mathrm{cpm}{ }^{125}$ I-PFR was added and incubation was carried out for another $18 \mathrm{~h}$ at $4^{\circ} \mathrm{C}$. IgG Sorb $(200 \mu \mathrm{l})$ was then added and the mixture incubated for another $2 \mathrm{~h}$ after which the IgG Sorb was sedimented in the microcentrifuge for $2 \mathrm{~min}$ at top speed. After aspiration of the supernatant, the pellet containing ${ }^{125} \mathrm{I}$-antigen-antibody complexed to IgG Sorb was counted for radioactivity. Each level of unlabeled PFR in the standard curve was performed in triplicate and the results expressed as the mean of the three assays. There was $<5 \%$ deviation from the mean at each point on the standard curve. For unknown samples subjected to evaluation for crossreacting material to the PFR, the sample solubilized in 2\% Triton X-100 and $1 \%$ deoxycholate was added in place of unlabeled PFR. Pilot studies (not shown) revealed that $2 \%$ Triton $\mathrm{X}-100$ and $1 \%$ deoxycholate did not affect the standard curve with respect to altering its sensitivity when compared with a simultaneous RIA performed in $1 \%$ Triton X-100. For unknown samples, a dose response (in triplicate) was routinely assessed to ensure that the assayed material was reasonably measurable in the mid-portion of the standard curve.

Density gradient and age dependent separation of erythrocytes. Stractan (arabinogalactan) was dissolved in distilled water (wt/wt) and passed through an Amberlite MB-4B column $(2.5 \times 30 \mathrm{~cm})$ twice to remove impurities and clarify the solution, as described earlier (20). This process reduced the osmolarity to $\sim 100 \mathrm{mosM} /$ liter. BSA (bovine serum albumin) powder $(3 \mathrm{~g})$ was added to the solution, which was further diluted to $291 \pm 1 \mathrm{mosM} /$ liter by the addition of buffered saline glucose (BSG) (20). The osmolarity and density of the solution were determined by an (model 2001, Precision Systems, Framingham, MA) osmometer and a refractometer (Abbe 3L, Fisher Scientific), respectively. Sucrose and Stractan solutions had the same osmolarity and density (data not shown). Stock solutions were further diluted with BSG to obtain the final concentrations given below. The osmolarity of each diluted sample was maintained at $291 \mathrm{mosM} / \mathrm{liter}$, and each solution was prepared fresh before the experiments and with desired densities determined by refractometry.

2-ml Stractan solutions (23-19\%) were successively layered on each other in a $15-\mathrm{ml} \mathrm{Beckman}$ polyallomer tube, and $1.5 \mathrm{ml}$ of freshly processed packed cells were layered on the top of the density gradient and separated using an SW 40 rotor for $55 \mathrm{~min}$ at $52,000 \mathrm{~g}$ at $4^{\circ} \mathrm{C}$ in a Beckman L8-55M ultracentrifuge. After centrifugation, each layer was 
carefully removed (beginning from the top) manually, or by using an 18-gauge needle attached to a peristaltic pump (both methods gave similar results).

${ }^{125}$ I-Labeled PteGlu (histamine derivative) binding to erythrocyte membranes was determined, as described above, after erythrocytes from each of seven Stractan density gradient-separated layers from 18 individual gradient tubes were pooled, washed three times with PBS, and then adjusted to a similar volume $\left(2 \times 10^{9}\right.$ cells per fraction $)$ before lysis in 15-ml Corex tubes. Radioligand binding and pyruvate kinase assays were performed within $4 \mathrm{~h}$ of venipuncture. These membranes were washed with lysis buffer, $\mathrm{pH}$ 5.5, to expose cryptic folate binding sites, as described above; this ensured that the observed radioligand binding was to both exposed and unmasked (cryptic) folate binding sites. Enzymatic measurements were determined at $25^{\circ} \mathrm{C}$ at $340 \mathrm{~nm}$, in a Perkin-Elmer Lambda 7 UV/VIS spectrophotometer (Perkin-Elmer Corp., Norwalk, CT). Each assay was performed in triplicate on a diluted hemolysate obtained through saponin treatment (21) of each layer of density-separated packed red cells and diluted with PBS. The assay system contained TEA buffer (85.6 mM, pH 7.6), PEP 0.521 $\mathrm{mM}$ (dissolved in $0.005 \mathrm{M} \mathrm{MgSO}_{4} / 0.2 \mathrm{M} \mathrm{KCl}$ ), ADP $6.7 \mathrm{mM}$ (neutralized with $1 \mathrm{M} \mathrm{KOH}$ ), and $\mathrm{LDH} 9.5 \mathrm{U} / \mathrm{ml}$. The reaction was initiated by the addition of $50 \mu \mathrm{l}$ of hemolysate (1:20) and the decrease in absorbance was recorded over $5 \mathrm{~min}$ at $22^{\circ} \mathrm{C}$. The slope of each recording was calculated and activity was expressed in units per milligram of hemoglobin using an extinction coefficient of NADH $=6.22(21)$.

Red cell and leukocyte counts were determined using a Coulter counter (model M 430, Coulter Electronics, Hialeah, FL). Manual counting of reticulocytes were routinely determined among 10,000 cells after staining with brilliant cresyl blue (22). Erythrocyte membranes from red cells separated on the basis of age were subsequently solubilized with $2 \%$ Triton $X-100$ and $1 \%$ deoxycholate, filtered through $0.2-\mu \mathrm{m}$ Millex-GV filters and analyzed for protein content (23). These samples were also subjected to the RIA to determine crossreacting material to the PFR as described above. Routinely, a dose response for each sample was assessed and the mean of three independent results (nanograms of cross-reacting material per milligram protein) was determined. A normal volunteer was subjected to phlebotomy of $300 \mathrm{ml}$ whole blood per week for 2 mo while on a normal diet. This resulted in an increase in reticulocyte count to $2.6 \%$. This individual's blood was used for study of erythrocyte FBPs after age-dependent separation of cells.

\section{Results}

Purity and stability of ${ }^{125}$ I-labeled PteGlu (histamine derivative). Preliminary studies using commercially available or synthesized $\left[{ }^{3} \mathrm{H}\right] \mathrm{PteGlu}$ and $5-$ methyl $-\left[{ }^{3} \mathrm{H}\right]$ tetrahydrofolate were unable to identify specific folate binding to erythrocyte membranes due to the small number of these exposed folate binding moieties on these cells. Only with the availability of a folate derivative with $\sim 40-50$-fold higher specific activity, was it possible to demonstrate P-FBPs on erythrocyte membranes. The structure of ${ }^{125} \mathrm{I}$-labeled PteGlu (histamine derivative) is shown in Fig. 1. The location of ${ }^{125} \mathrm{I}$ is on the histamine ring, although its exact position has not been determined. Although this is an unnatural form of radiolabeled folate, its affinity for other FBPs from human placenta and milk was comparable to that obtained using $\left[{ }^{3} \mathrm{H}\right]$ or $\left[{ }^{14} \mathrm{C}\right] \mathrm{PteGlu}$ in pilot studies. Studies were therefore undertaken to establish the purity of ${ }^{125} \mathrm{I}$-labeled PteGlu (histamine derivative) as well as its stability under the experimental conditions used in these studies. This was accomplished by conventional analytical procedures with HPLC and TLC. Fig. 2 shows the HPLC elution profile of commercially supplied ${ }^{125}$ I-labeled PteGlu (histamine derivative). There was a only single peak of radioactivity that corresponded to the maximum absorbance $\left(A_{280}\right)$ of ${ }^{125}$ I-labeled<smiles></smiles>

Figure 1. Structure of a derivative of folic acid for iodination, 1-carboxy-3-( $N$-(2-(4-imidazolyl)ethyl)carbamoyl)1-pteroylaminopropane [ ${ }^{125}$ I-labeled PteGlu (histamine derivative)].

PteGlu (histamine derivative), indicating its purity; when the peak fraction was reinjected into the column, the elution profile was identical to that of the commercially available ${ }^{125} \mathrm{I}-\mathrm{la}$ beled PteGlu (histamine derivative). Furthermore, there was no change in the elution profile or additional peaks of radioactivity after incubation of the HPLC-purified radiolabeled material for $2 \mathrm{~h}$ at $37^{\circ} \mathrm{C}$. These findings confirmed that ${ }^{125} \mathrm{I}$-labeled PteGlu (histamine derivative) was greater than $99 \%$ pure and stable over the entire period of experiments detailed below. To verify purity by another method, both unfractionated (commercially available) and HPLC-purified ${ }^{125} \mathrm{I}$-labeled PteGlu (histamine derivative) were analyzed by TLC. As shown in Fig. 3, both preparations were identical in their migration on microcrystalline cellulose. In the unfractionated sample however, there was a faint additional band (which did not correspond to free ${ }^{125} \mathrm{I}$ and is poorly reproduced in the figure) comprising $<1 \%$ of the major species; this was not found in the HPLC fractionated sample. To determine if the major form of ${ }^{125} \mathrm{I}$-labeled PteGlu (histamine derivative) from the unfractionated preparation exhibited comparable binding to erythrocyte membranes as HPLC-purified ${ }^{125} \mathrm{I}$-labeled PteGlu (histamine derivative), a dose-response curve with increasing concentrations of the two preparations was deter-

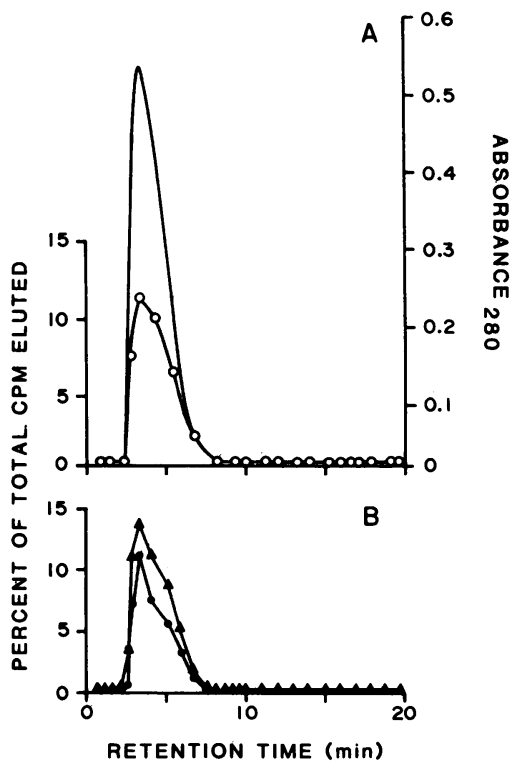

Figure 2. HPLC analysis of ${ }^{125}$ I-labeled PteGlu (histamine derivative). (A) $50 \mathrm{fmol}$ $(10 \mu l)$ of unfractionated (commercially available) radiolabeled folate was applied to a $3.9 \mathrm{~mm} \times 30 \mathrm{~cm} \mathrm{C} 18$ $\mu$ Bondapak column that was isocratically equilibrated and eluted at a flow rate of $1 \mathrm{ml} /$ min with $5 \mathrm{mM}$ PicA, $10 \mathrm{mM} \mathrm{KH}_{2} \mathrm{PO}_{4} /$ $\mathrm{H}_{3} \mathrm{PO}_{4}$, pH 5.5 (buffer A), and acetonitrile (buffer B) at $84 / 16 \%$, respectively. Absorbance at $280 \mathrm{~nm}(0.05$ AUFS) was monitored and $0.5 \mathrm{ml}$ fractions were collected and

counted for radioactivity (O). (B) The peak fraction from (A) was reapplied to the column before $(\triangle)$ and after $(\bullet)$ incubation for $2 \mathrm{~h}$ at $37^{\circ} \mathrm{C}$ and fractions were counted for radioactivity. 


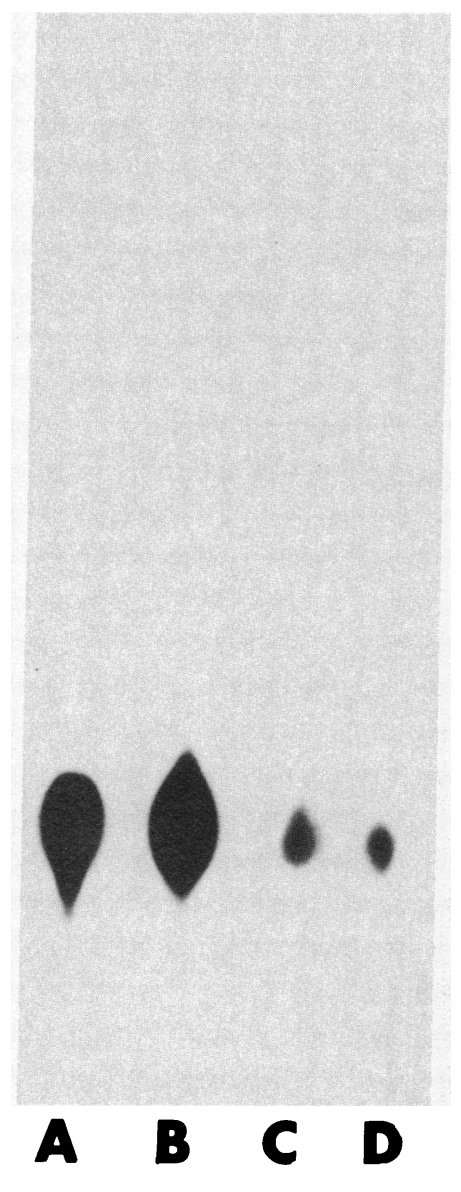

Figure 3. TLC analysis of ${ }^{125} \mathrm{I}$ labeled PteGlu (histamine derivative). $5 \mu \mathrm{l}$ of sample was applied to microcrystalline cellulose plates that were developed in $N$-propanol/ $/ \mathrm{NH}_{4} \mathrm{OH}$ 7:3 and plates were subjected to autoradiography. $(A)$ Commercially available radiolabeled material. (B) HPLC purified (peak fraction) ${ }^{125} \mathrm{I}$-labeled PteGlu (histamine derivative). ( $C$ ) Commercially available radiolabeled material that was specifically bound to erythrocyte membranes and eluted with lysis buffer, $\mathrm{pH} 5.5$ (D) HPLC-purified ${ }^{125}$ I-labeled PteGlu (histamine derivative) that was specifically bound to erythrocyte membranes and eluted with lysis buffer, pH 5.5.

mined. As shown in Table I, both unfractionated and HPLCpurified ${ }^{125}$ I-labeled PteGlu (histamine derivative) preparations bound erythrocyte membranes with similar high specificity and comparable extent. Finally, to verify that the radioactive species in unfractionated and HPLC-purified ${ }^{125} \mathrm{I}-$ labeled PteGlu (histamine derivative) that specifically bound to erythrocyte membranes was in fact ${ }^{125}$ I-labeled PteGlu (histamine derivative), membranes containing only bound radioligand were washed with lysis buffer, $\mathrm{pH}$ 5.5. This maneuver eluted $>90 \%$ of specifically bound radioactivity (see below); the eluates were subsequently analyzed by TLC. As shown in Figs. 3, $C$ and $D$, only one species of radiolabeled material corresponding to HPLC-purified ${ }^{125}$ I-labeled PteGlu (histamine derivative) was observed. This suggested that the ${ }^{125} \mathrm{I}-\mathrm{la}$ beled PteGlu (histamine derivative) was unaltered following its binding to erythrocyte membranes. Although we have no data to directly prove that the radioactive label was not transferred in the course of these experiments (but remained in the imidazole ring), the experiments detailed above, as well as the fact that the iodination of the histamine derivative of folic acid with chloramine $T$ involved covalent linkage, suggest that the radioactive label was authentic ${ }^{125}$ I-labeled PteGlu (histamine derivative). There was no significant loss of purity or erythrocyte membrane binding capacity even after $2 \mathrm{wk}$ of storage of radioactive material at $4^{\circ} \mathrm{C}$ (not shown). Taken together, the data suggested that $(a)$ commercially available unfractionated ${ }^{125}$ I-labeled PteGlu (histamine derivative) was of a high degree of purity as evidenced by a single species at $\mathrm{A}_{280}$, which corresponded to the major $(>99 \%)$ peak of radioactivity in eluted
Table I. Binding of Commercially Available and HPLC-purified ${ }^{125}$ I-Labeled PteGlu (Histamine Derivative) to Erythrocyte Membranes*

\begin{tabular}{lll}
\hline & $\begin{array}{l}\text { Specific } \\
\text { (histamine derivative) bound }\end{array}$ & \\
\cline { 2 - 3 } $\begin{array}{l}\text { Concentration of } \\
\text { 125I-labeled PteGlu } \\
\text { (histamine derivative) }\end{array}$ & $\begin{array}{l}\text { Commercially } \\
\text { available radioligand }\end{array}$ & $\begin{array}{l}\text { HPLC-purified } \\
\text { radioligand }\end{array}$ \\
\hline$p M$ & $f m o l$ & fmol \\
12.5 & 1.2 & 1.2 \\
25 & 1.6 & 1.3 \\
50 & 2.0 & 1.8 \\
\hline
\end{tabular}

* Erythrocyte membranes, $0.5 \mathrm{ml}$, which were prewashed to remove endogenous bound folate as described in Methods, were incubated with various concentrations of commercially available and HPLCpurified ${ }^{125} \mathrm{I}$-labeled PteGlu (histamine derivative) for $1 \mathrm{~h}$ at $37^{\circ} \mathrm{C}$ in a final volume of $1 \mathrm{ml}$ lysis buffer, $\mathrm{pH} 7.5$, in the absence (total binding) and presence of a 1,000-fold excess unlabeled PteGlu (nonspecific binding). Unbound radioactivity was removed by three cen-

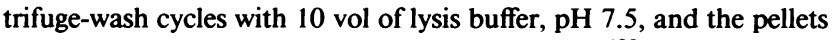
were counted for radioactivity. Specifically bound ${ }^{125}$ I-labeled PteGlu (histamine derivative) was the difference between total and nonspecific binding and constituted $>90 \%$ of total binding.

${ }^{\ddagger}$ Each data point represents the mean of three values that had $<5 \%$ variation from the mean.

fractions (HPLC) and major species (> 99\%) of radiolabeled material (TLC); $(b)$ this commercially available ${ }^{125}$ I-labeled PteGlu (histamine derivative) bound erythrocyte membranes with a high degree of specificity and to a comparable extent as HPLC-purified radioactive material; and (c) following specific binding to erythrocyte membranes by commercially available and HPLC-purified ${ }^{125}$ I-labeled PteGlu (histamine derivative) and subsequent elution of bound radioactivity, there was no detectable change in the relative migration of eluted radioactivity on TLC when compared with HPLC-purified radioligand, indicating that authentic ${ }^{125}$ I-labeled PteGlu (histamine derivative) was responsible for binding to erythrocyte membranes.

Erythrocyte membrane folate binding characteristics. As shown in Fig. $4 A$, washed purified human erythrocyte membranes specifically bound ${ }^{125}$ I-labeled PteGlu (histamine derivative), and nonspecific binding accounted for $<5 \%$ of total folate binding. Specific folate binding, defined as the difference between radioligand binding in the presence (nonspecific) and absence (total) of a 1,000-fold excess of unlabeled PteGlu, was saturable, while nonspecific folate binding was linear and not saturable. The binding isotherms indicated a single high affinity folate binding site with a dissociation constant of 3.3 $\times 10^{-11} \mathrm{M}$ (Fig. $4 \mathrm{~B}$ ). Folate binding linearly increased as a function of erythrocyte membrane concentration (Fig. $4 \mathrm{C}$ ), and was time and temperature dependent; ligand binding equilibrium was reached by $1 \mathrm{~h}$ at $37^{\circ} \mathrm{C}$ and $6 \mathrm{~h}$ at $4^{\circ} \mathrm{C}$ (Fig. $4 \mathrm{D}$ ). The $\mathrm{pH}$ optimum for ligand binding was 7.5 (Fig. 4 E, closed bars). To determine if the observed decrease in folate binding at lower $\mathrm{pH}$ was due to alteration in ligand binding capacity or to destruction of folate binding sites (as a result of washing membranes with low $\mathrm{pH}$ buffers), the $\mathrm{pH}$ of membranes were neutralized and folate binding studies were repeated. Under these conditions there was up to a fourfold increase in folate 

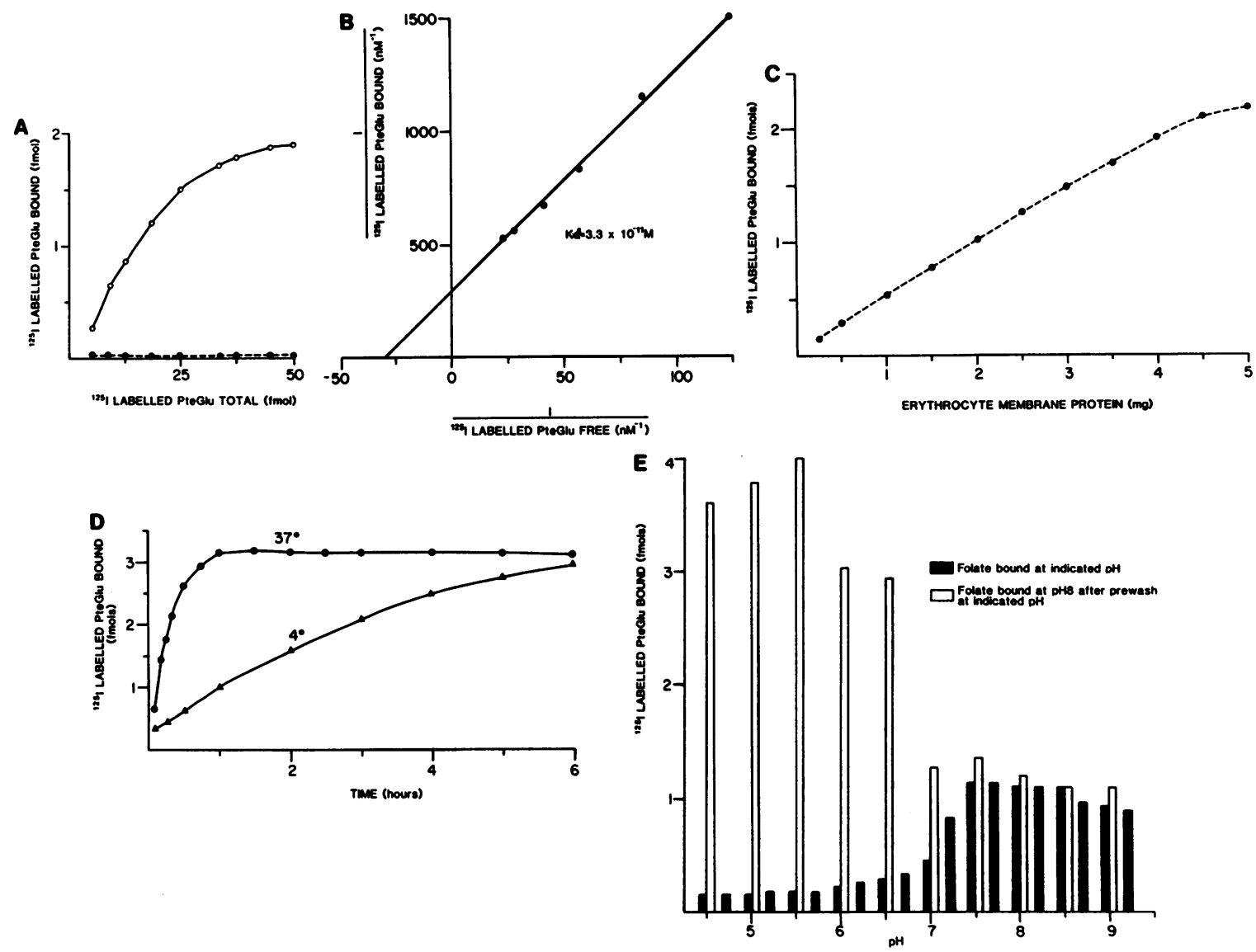

Figure 4. Erythrocyte membrane folate binding characteristics. $(A)$ saturability and specificity; Erythrocyte membranes $(1.3 \mathrm{ml})$ were incubated with increasing concentrations of ${ }^{125} \mathrm{I}$-labeled PteGlu (histamine derivative) in the absence ( 0 ) and presence ( $\bullet$ ) of a 1,000-fold excess of unlabeled PteGlu in a final volume of $2 \mathrm{ml}$ lysis buffer consisting of $10 \mu \mathrm{mol}$ sodium phosphate, $\mathrm{pH} 8$, and $20 \mathrm{nmol}$ magnesium sulfate, $40 \mu \mathrm{g}$ PMSF, and membranes washed in lysis buffer were counted for radioactivity. $(B)$ affinity: The dissociation constant of folate interaction with membranes. $(C)$ Substrate dependence: 50 fmol ${ }^{125}$ I-labeled PteGlu (histamine derivative) were incubated with increasing concentrations of membranes in a final volume of $1 \mathrm{ml}$ lysis buffer. $(D)$ Time and temperature dependence: membranes, $(2.75 \mathrm{ml})$, were incubated at $4^{\circ} \mathrm{C}(\Delta)$ or $37^{\circ} \mathrm{C}(\bullet)$ with $25 \mathrm{pM}{ }^{125} \mathrm{I}$-la-

bound to samples prewashed with low $\mathrm{pH}$ buffers when compared to samples maintained at pH 8.0. (Fig. $4 E$, open bars). This increase in folate binding was not due to an increase in affinity, which was identical to that shown in Fig. $4 B\left(K_{d}=3.3\right.$ $\times 10^{-11} \mathrm{M}$ ) and was likely due to unmasking of folate binding sites that were occupied by endogenous folate (cryptic folate binding sites). This possibility was confirmed by washing membranes containing bound radiolabeled folate with $\mathrm{pH} 5.5$ buffer, which led to $\sim 90 \%$ release of the bound radioligand (data not shown). These studies support the conclusion that prewashing membranes with low $\mathrm{pH}$ buffers resulted in endogenous folate removal and unmasking of cryptic folate binding sites. The equivalent affinity between exposed and total (exposed and unmasked cryptic) folate binding sites also suggested that exposed and cryptic folate binding sites have functional similarities. It is not known if a significant number of beled PteGlu (histamine derivative) in $3 \mathrm{ml}$ lysis buffer and at various times the membrane pellets assayed for bound radioactivity. $(E)$ pH dependence: membranes $(1 \mathrm{ml})$, were incubated with $25 \mathrm{fmol}$ ${ }^{125}$ I-labeled PteGlu (histamine derivative) in lysis buffers of varying pH. After washing membranes with the same $\mathrm{pH}$ buffer that they were incubated with radioligand, the pellets were counted for radioactivity (solid bars). These membranes were subsequently washed with lysis buffer, $\mathrm{pH} 8$, and reincubated with $25 \mathrm{fmol}{ }^{125}$ I-labeled PteGlu (histamine derivative); the results of specific radioligand uptake under these conditions (open bars). Unless specified, all incubations were for $1 \mathrm{~h}$ at $37^{\circ}$ and unbound folate removed by centrifugewash cycles as described under Methods.

erythrocyte membrane folate binding sites are occupied by endogenous folates in vivo.

Since a derivative of folate $\left[{ }^{125}\right.$ I-labeled PteGlu (histamine derivative)] was used as the radioligand in this study, it was important to determine if its affinity for particulate erythrocyte membrane FBPs was similar to authentic pteroylmonoglutamate. The results of the competitive inhibition studies using unlabeled PteGlu (Fig. 5) suggested that erythrocyte PFBPs had similar affinity for the commercially available iodinated histamine derivative of PteGlu as for unlabeled PteGlu. This was indicated by the ability of equimolar concentrations of unlabeled PteGlu in reducing ${ }^{125}$ I-labeled PteGlu (histamine derivative) binding to erythrocyte membranes by $50 \%$. The results with various folate analogues indicated higher affinities for PteGlu and 5-methyltetrahydrofolate than 5-formyltetrahydrofolate and amethopterin. Under these 


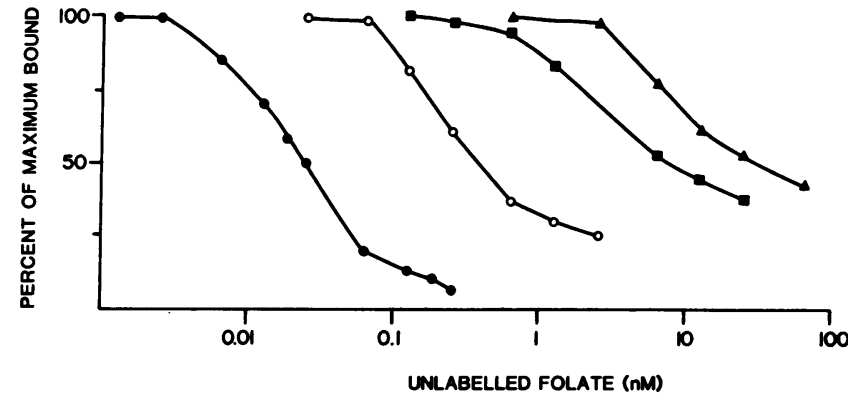

Figure 5. Competitive inhibition of ${ }^{125} \mathrm{I}$-labeled PteGlu (histamine derivative) binding to erythrocyte membranes by unlabeled folates. Membranes $(1 \mathrm{ml})$ were suspended with $50 \mathrm{fmol}{ }^{125} \mathrm{I}$-labeled PteGlu (histamine derivative) in the absence (maximum bound) and presence of increasing concentrations of unlabeled PteGlu (•), d, 1-5methyltetrahydrofolate (0), 5-formyltetrahydrofolate ( $(0)$ or amethopterin ( $\Delta$ ) in a final volume of $2 \mathrm{ml}$ of lysis, $\mathrm{pH} \mathrm{8}$, buffer containing $200 \mu \mathrm{mol} 2-\mathrm{ME}$. After incubation for $1 \mathrm{~h}$ at $37^{\circ} \mathrm{C}$, the membranes were washed and assessed for bound radioactivity.

experimental conditions, it would suggest that $d, 1-5$-methyltetrahydrofolate had an $\sim 5-10$-fold less affinity for binding erythrocyte membranes compared with PteGlu. When this is related to human serum folate concentrations (5-40 $\mathrm{nM}$ ) and the dissociation constant of folate binding by these membranes, it appears that this affinity is in the range for binding folates in serum. Similar findings have been reported with particulate folate binding proteins in human placenta, milk, and $\mathrm{KB}$ cells and other mammalian cells $(3,5-7,12,18$, 24-29), further supporting the possibility that these proteins may have some physiological relevance in binding serum folates.

Solubilization and identification of membrane FBPs. We found that $2 \%$ NP-40 and 2\% Triton X-100 led to the solubilization of specific folate binding moieties that eluted on Sephacryl S-200 in the void volume $\left(M_{\mathrm{r}} \geq 200,000\right)$ as well as at $M_{\mathrm{r}}$ 160,000 (Fig. $6 \mathrm{~A}$ ). The third radioactive peak at $V_{e} / V_{o}=3.5$ represented the elution position of free ${ }^{125} \mathrm{I}$-labeled PteGlu (histamine derivative). Duplicate studies of membranes solubilized and incubated with similar ${ }^{125} \mathrm{I}$-labeled PteGlu (histamine derivative) concentrations but also containing a 1,000fold excess of unlabeled PteGlu resulted in virtually complete quenching of the folate binding peak corresponding to $M_{\mathrm{r}}$ 160,000 , similar to those results found among FBPs identified in human placenta, milk, and KB cells $(3,8,18)$. Although there was a significantly higher amount of nonspecific binding by the minor peak eluting in the void volume, there was nevertheless a peak of specific folate binding in this fraction that could be due to incomplete solubilization of this moiety out of erythrocyte membranes. The greater degree of nonspecific binding, although possibly unique to this FBP in comparison to FBPs from other human tissues $(3,8,18)$ may also be explained by the coelution of other $\geq 200,000 M_{\mathrm{r}}$ proteins that have nonspecific folate binding properties. No FBP was identified in the $M_{\mathrm{r}} 40,000$ range, which was the elution position for the major solubilized membrane FBP from human placenta (3); these were similar results, however, to those found with human KB cells that had a single $160,000 M_{\mathrm{r}}$ FBP (8).

Studies were further extended to determine if the eluted FBPs after Sephacryl S-200 gel filtration were recognized by

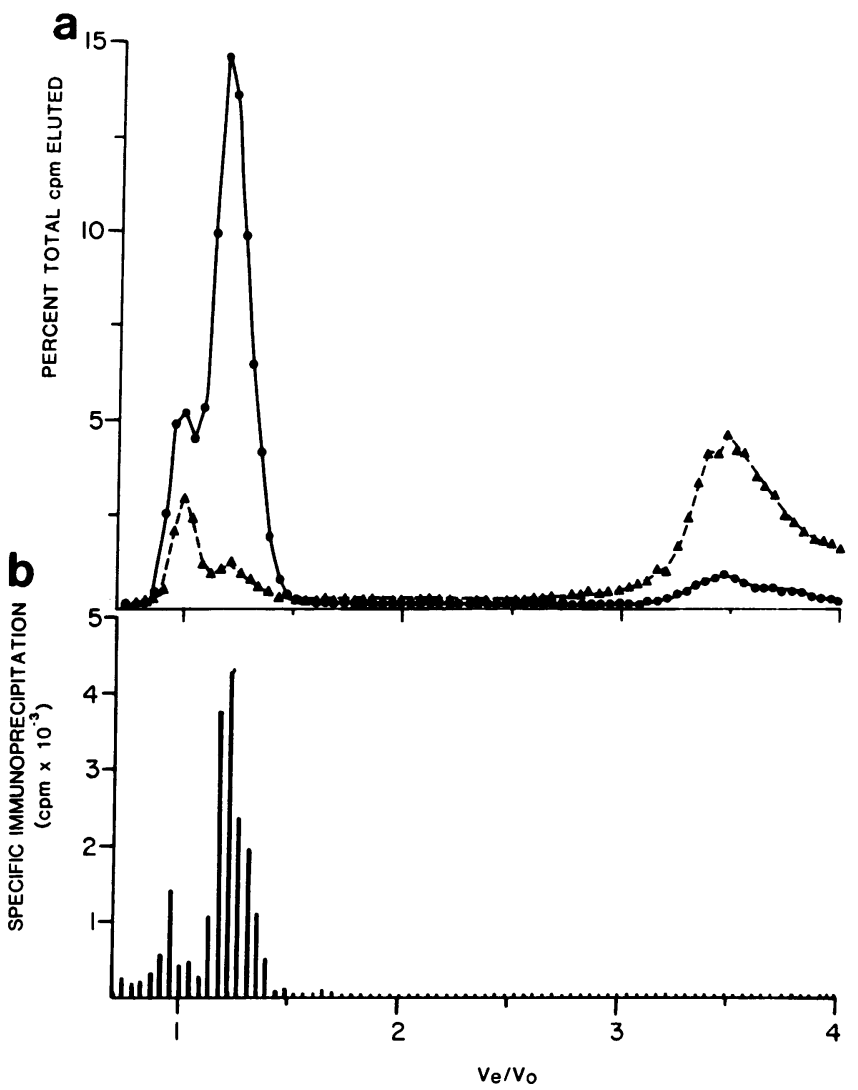

Figure 6. Gel filtration chromatography and identification of erythrocyte membrane FBPs. $(A) 20 \mathrm{ml}$ of erythrocyte membranes were treated to remove endogenous folate (see Methods), concentrated, and solubilized with $2 \%$ Triton X-100 and $2 \%$ NP-40 for $24 \mathrm{~h}$ at $4^{\circ} \mathrm{C}$. The supernatant $(3 \mathrm{ml})$ after ultracentrifugation was filtered, and incubated with $250 \mathrm{fmol}{ }^{125} \mathrm{I}$-labeled PteGlu (histamine derivative) $\left(8.6 \times 10^{5} \mathrm{cpm}\right)$ in the absence $(\bullet)$ and presence $(\triangle)$ of $250 \mathrm{pmol}$ unlabeled PteGlu and applied over a $2.5 \times 30 \mathrm{~cm}$ Sephacryl S-200 column that was equilibrated and eluted with $0.01 \mathrm{M} \mathrm{KPO}_{4}, \mathrm{pH} 7.5$, containing 1\% Triton X-100. Fractions of $2.75 \mathrm{ml}$ were collected and counted for radioactivity. The recovery of total applied radioactivity in eluted fractions was $90 \%$. (B) $1 \mathrm{ml}$ of erythrocyte membranes were iodinated, solubilized, and subjected to gel filtration as above. Each eluted fraction was divided into two $1.350-\mathrm{ml}$ aliquots and incubated with either $10 \mu \mathrm{l}$ crude rabbit anti-human placental folate receptor immune serum or preimmune serum for $16 \mathrm{~h}$ at $4^{\circ} \mathrm{C}$. After adding IgG Sorb, $(100 \mu \mathrm{l})$, and incubation for $30 \mathrm{~min}$ at $4^{\circ} \mathrm{C}$, the mixture was centrifuged to sediment IgG Sorb bound antibody complexed to iodinated proteins. The data in each eluted fraction is the difference between the precipitated radioactivity obtained using immune serum and preimmune serum. Both qualitatively and quantitatively similar results were obtained on five different studies on blood from the same individual.

antibody to the purified human placental folate receptor (3). Although the ${ }^{125} \mathrm{I}$-labeled PteGlu (histamine derivative)-bound FBPs eluting from the gel filtration column could be specifically immunoprecipitated with purified IgG from immune serum raised against the PFR using either 5\% polyethylene glycol or proteins A bearing $S$. aureus cells, the quantity of specifically precipitated FBPs was consistently lower in comparison to the total radioactivity in each FBP peak (data not shown). The reason for this was not clear but could be related 
to a higher proportion of blocking compared to immunoprecipitating antibodies in the polyclonal antiserum raised against the purified protein; these blocking antibodies could potentially displace bound ${ }^{125} \mathrm{I}$-labeled PteGlu (histamine derivative) from the FBPs. Therefore, after iodination of erythrocyte membranes followed by solubilization and Sephacryl S-200 gel filtration chromatography, the eluted fractions were probed with rabbit immune and preimmune serum. The results (Fig. 6 $B)$, identified two peaks of specifically immunoprecipitated material in the void volume and at $M_{\mathrm{r}} 160,000$ corresponding to the elution position of ${ }^{125} \mathrm{I}$-labeled PteGlu (histamine derivative)-bound FBPs (Fig. $6 \mathrm{~A}$ ). Although solubilized iodinated membranes contained a moiety that was specifically immunoprecipitated by anti-PFR serum, findings consistent with earlier immunofluorescent studies (3), it was nevertheless necessary to determine if this species was a folate binding protein. We found that $90 \%$ of the ${ }^{125}$ I-labeled PteGlu (histamine derivative) previously bound to membranes was released into the supernatant after treatment of membranes with $2 \%$ Triton $\mathrm{X}-100$ and $1 \%$ sodium deoxycholate. When the supernatant was reacted with increasing concentrations of anti-PFR anti-

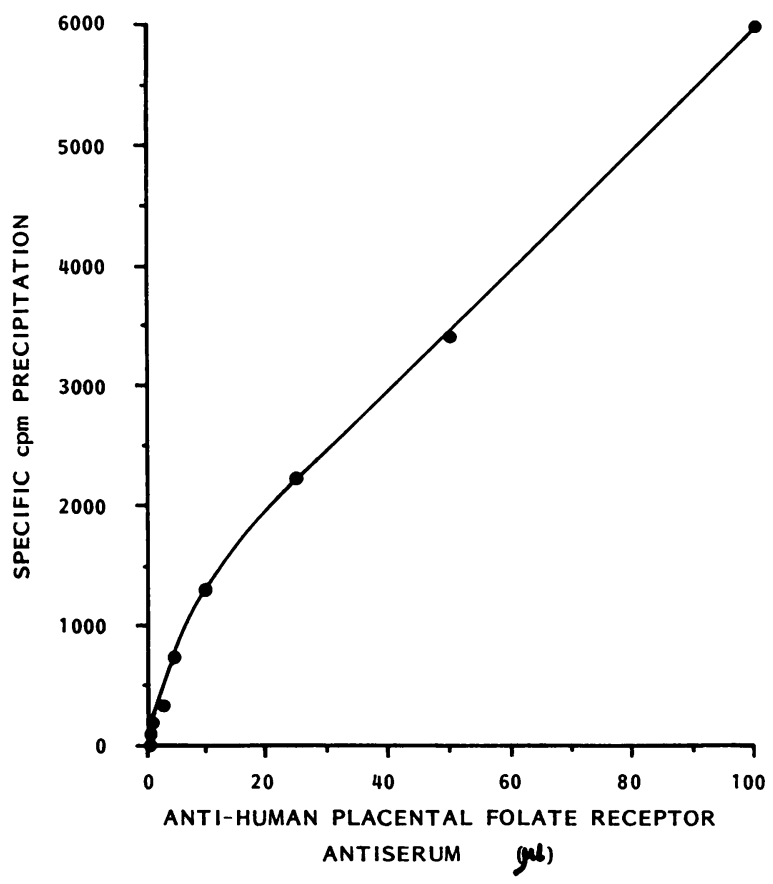

Figure 7. Immunoprecipitation of solubilized erythrocyte folate binding protein by anti-human placental folate receptor serum. Tubes containing $5 \mathrm{mg}$ of membranes that had bound ${ }^{125} \mathrm{I}$-labeled PteGlu (histamine derivative) were solubilized with lysis buffer containing $2 \%$ Triton X-100 and $1 \%$ deoxycholate over $18 \mathrm{~h}$. After centrifugation at $30,000 \mathrm{~g}$ for $60 \mathrm{~min}$ at $4^{\circ} \mathrm{C}$ to remove insoluble material, the supernatants $(2.9 \mathrm{ml})$ were incubated with increasing concentrations of crude rabbit anti-human placental folate receptor antiserum diluted in $100 \mathrm{ml}$ preimmune serum for $18 \mathrm{~h} .1 \mathrm{ml}$ of $20 \%$ polyethylene glycol (wt/vol) was added to each tube and the mixture incubated for $10 \mathrm{~min}$. After centrifugation at $30,000 \mathrm{~g}$ for $60 \mathrm{~min}$ the supernatants were aspirated and the pellets counted for radioactivity. Specific precipitation of ${ }^{125}$ I-labeled PteGlu (histamine derivative)bound solubilized FBP was determined from the difference between precipitated radioactivity in tubes containing various concentrations of antiserum and preimmune serum. serum, there was a linear increase in specific precipitation of ${ }^{125}$ I-labeled PteGlu (histamine derivative)-bound protein (Fig. 7) which, at $100 \mu \mathrm{l}$ antiserum, constituted $38 \%$ of the total radioactivity. The inability to precipitate $100 \%$ of protein bound radioligand could be due to $(a)$ competitive displacement of radioligand by unlabeled folates present in rabbit antiserum, or $(b)$ partial homology of antigenic determinants between the erythrocyte FBP and PFR. The fact that the crude antiserum contained a higher concentration of folate (100 nM) compared with $37.5 \mathrm{nM}$ folate present in preimmune serum could explain the former possibility. However, since preimmune serum precipitated $<5 \%$ of the total radioligand-bound protein at all levels compared to antiserum, the results nevertheless indicate that the erythrocyte FBP shared epitopes with the PFR. Taken together, the ligand binding data as well as the immunological studies suggest that the two erythrocyte membrane folate binding proteins were antigenically related to the FBPs from human milk, placenta, and KB cells, which share antigenic determinants that are recognized by the antiserum used in this study $(3,8,18-19)$. The purified FBPs with apparent $M_{\mathrm{r}}$ of 160,000 on gel filtration in Triton X-100 from human milk (18) and $\mathrm{KB}$ cells $(8,24,30)$ are hydrophobic detergent binding proteins, findings that are consistent with their association with membranes; it is therefore possible that the erythrocyte $160,000 M_{\mathrm{r}}$ FBPs may have similar characteristics. Although the $\geq 200,000 M_{\mathrm{r}}$ FBP may be unique to erythrocyte membranes, a more trivial explanation may be the incomplete solubilization from erythrocyte membranes by the non-ionic detergents used in this study. Further characterization of detergent binding and the $M_{\mathrm{r}}$ of these proteins by native and denaturing gel electrophoresis has been attempted; preliminary studies indicate, however, that further purification of these proteins is required due to the small amounts of these P-FBPs in erythrocytes (see below).

Identification of nonfunctional FBPs. Scatchard analysis from the folate binding isotherms indicated that in spite of removal of endogenous folate by "acid stripping" washes, there was less than one functional (in folate binding) molecule of FBP per erythrocyte. These results were not consistent with previous immunofluorescence studies on erythrocytes (3) that revealed both linear and beaded fluorescence in virtually every cell (albeit in varying degrees) when probed with anti-human PFR serum. A gross underestimation of functional folate binding protein could be possible if a large amount of endogenous folate remained bound even after acid washing of membranes. However, when purified membranes (from $10 \mathrm{ml}$ of erythrocytes) were assayed for the presence of endogenous folate by boiling for $30 \mathrm{~min}$ in the presence of reducing agents $(8,18)$, no folate was released (detected) in the supernatant. To determine whether there was folate that remained bound to membrane FBPs even after the boiling process, two (indirect) tests were employed to investigate if FBPs were denatured and lost the ability to bind folate. In the first instance, membranes failed to bind ${ }^{125}$ I-labeled PteGlu (histamine derivative) after they were boiled; secondly, boiling membranes released $100 \%$ of bound ${ }^{125}$ I-labeled PteGlu (histamine derivative). Thus it was unlikely that endogenous folate remained bound to membrane FBPs to account for our inability to detect it in the assay for endogenous folate. We therefore hypothesized the presence of nonfunctional but immunoreactive folate binding proteins in these cells. 

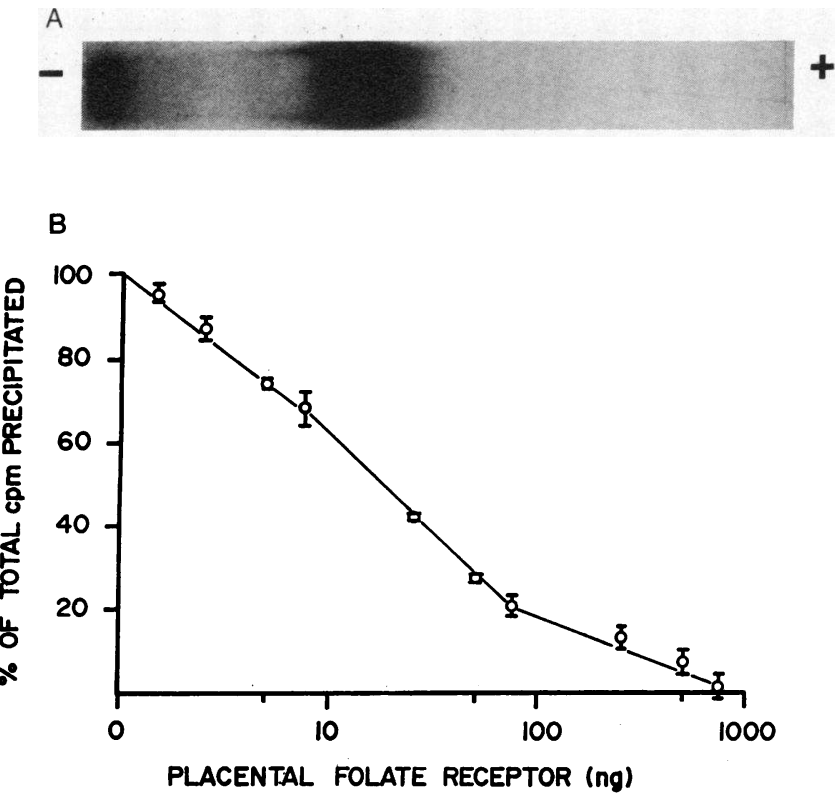

Figure 8. (A) Sodium dodecyl sulfate polyacrylamide gel electrophoresis and autoradiography of iodinated placental folate receptor $100,000 \mathrm{cpm}$ of affinity purified ${ }^{125}$ I-PFR (see Methods) were detritonized and run on $15 \%$ slab gels. After drying, the gels were subjected to autoradiography using Kodak X-Omat AR film and Cronex Lightning-Plus intensifying screens for $8 \mathrm{~h}$ at $-70^{\circ} \mathrm{C}$. The gel was run from left to right and the major band corresponds to a $M_{\mathrm{r}}=$ 40,000 , while the minor band (containing aggregated material that failed to enter the gel) corresponds to the origin. (B) Standard RIA curve for the PFR. Tubes containing $20 \mu l$ anti-human PFR serum (diluted 1:100 in preimmune serum) and increasing concentrations of unlabeled PFR diluted in a final volume of $500 \mu \mathrm{l} 0.01 \mathrm{M} \mathrm{KPO}_{4}$, pH 7.5, containing $1 \%$ Triton X-100 were incubated for $18 \mathrm{~h}$ at $4^{\circ} \mathrm{C}$. 125 I-PFR, $10,000 \mathrm{cpm}$, was then added and incubation continued for an additional $18 \mathrm{~h}$. IgG Sorb, $200 \mu \mathrm{l}$, was subsequently added and after $2 \mathrm{~h}$ at $4^{\circ} \mathrm{C}$, the ${ }^{125} \mathrm{I}$-PFR-antibody complexes bound to IgG Sorb were sedimented and counted for radioactivity. Preimmune serum, $20 \mu$ l, nonspecifically precipitated $28 \%$ of the total ${ }^{125}$ I-PFR, and this value, when subtracted from that precipitated with $0.2 \mu \mathrm{l}$ immune serum, gave the $100 \%$ value $(4,000 \mathrm{cpm})$ on the ordinate.

To test this possibility, a RIA was constructed that was based on the competitive binding of purified iodinated (Fig. 8 $A)$ and unlabeled placental folate receptor by crude rabbit anti-human PFR serum; ${ }^{125}$ I-antigen-antibody complexes were immunoprecipitated with protein A-bearing Staphylococcus aureus cells. The standard RIA assay curve (Fig. 8 B) had an upper limit of sensitivity of $5 \mathrm{ng}(0.1 \mathrm{pmol})$ and a lower limit of sensitivity of $500 \mathrm{ng}$ ( $10 \mathrm{pmol}$ ) PFR. When solubilized erythrocyte membranes were tested in the RIA, they were found to contain $160 \pm 20 \mathrm{ng}$ cross-reacting material/mg protein; this constituted $0.016 \%$ of the total solubilized erythrocyte membrane proteins. When the value of cross-reacting material per milligram of protein was converted to molar equivalents of FBPs and thence to molecules of protein per erythrocyte, (assuming that the true $M_{\mathrm{r}}$ of the FBP was $\sim 44,000$ as has been shown with solubilized particulate FBPs from milk [18] and $\mathrm{KB}$ cells [30]), there were $\sim 1,500 \pm 150$ molecules/erythrocyte. It was therefore evident that there was a significant component of nonfunctional but immunoreactive FBP in erythrocytes.
Relationship between folate binding protein and red cell age. To determine if all of the observed folate binding was accounted by contaminating reticulocytes in the relatively heterogeneously aged population of erythrocytes in a given sample of blood, we determined (a) the folate binding capacity and $(b)$ amount of immunoreactive FBP in membranes from cells separated on the basis of age. The age-related fractionation of leukocyte-free red cells was based on the earlier findings

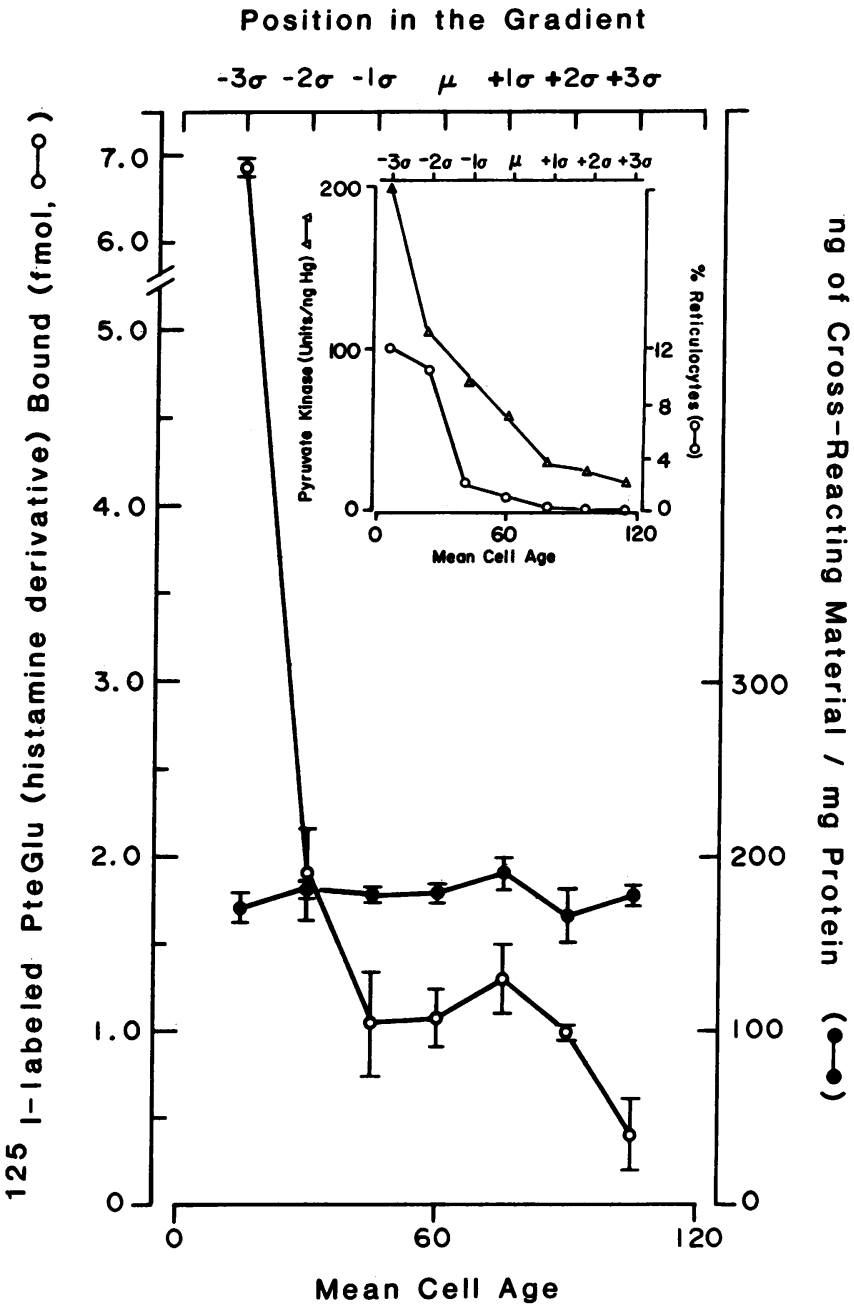

Figure 9. ${ }^{125} \mathrm{I}$-Labeled PteGlu (histamine derivative) binding to erythrocyte membranes and RIA on solubilized membranes from erythrocytes separated by Stractan density gradients. $2 \times 10^{9}$ cells from each of seven layers of erythrocytes separated by Stractan density gradients were lysed and after exposure of cryptic folate binding sites as described in Methods were assessed for folate binding ( 0 ) using $0.1 \mathrm{nM}^{125}$ I-labeled PteGlu (histamine derivative). Control (unfractionated) erythrocyte membranes (from $2 \times 10^{9}$ cells) bound 1.1 fmol ${ }^{125}$ I-labeled PteGlu (histamine derivative). Membranes of known protein content from each separate were solubilized and assessed for cross-reacting material to the PFR by RIA (•). Inset shows the pyruvate kinase activity and percent reticulocytes in each erythrocyte fraction after density gradient separation. $-/+\sigma$ on the abcissa shows the position in the gradient from top ( $-\sigma$ youngest cells) to bottom ( $+\sigma$ aged cells). Mean cell age was calculated as previously described (31). Each data point was the mean $\pm S E$ of experiments performed in triplicate. Similar results were obtained on three different occasions. 
$(20,31)$ that red cells became more dense as they aged and could be separated on this basis by Stractan density gradients. Parameters of aging red cells included the measurement of reticulocytes (youngest circulating erythrocytes) and the activity of the enzyme pyruvate kinase (PK), which decreases with increasing cell age. As shown in Fig. 9, inset, the concentration of reticulocytes in the fractions declined rapidly from top to bottom and virtually no measurable reticulocytes were demonstrated in the bottom fraction (which contained aged red cells), whereas the maximum reticulocytes $(12 \%)$ were concentrated in the top fraction. The PK activity was also maximum in the top fraction of the gradient and progressively declined; cells in the bottom fraction contained a 10-fold lower PK activity thus confirming the validity of the gradient in separating cells on the basis of their age. Also shown in Fig. 9, a 6.75-fold higher binding capacity of ${ }^{125} \mathrm{I}$-labeled PteGlu (histamine derivative) was observed in membranes from young cells when compared with an equivalent number of unfractionated (control) red cells. No correlation was identified between the binding of ${ }^{125} \mathrm{I}$-labeled PteGlu (histamine derivative) to the various cell cohorts after fractionation and the number of reticulocytes per fraction. These findings excluded the possibility that the observed ${ }^{125}$ I-labeled PteGlu (histamine derivative) to unfractionated cells was due to contamination by reticulocytes. However, these results also showed that the degree of ${ }^{125}$ I-labeled PteGlu (histamine derivative) binding to red cells markedly decreased at the onset of red cell aging. Scatchard analysis (32) of ${ }^{125} \mathrm{I}$-labeled PteGlu (histamine derivative) binding isotherms on erythrocyte membranes from the youngest cohort of erythrocytes revealed a single high affinity binding site and an essentially similar dissociation constant $\left(K_{d}=4 \times 10^{-11} \mathrm{M}\right)$ compared with unfractionated and aged erythrocytes $\left(K_{d}=3.3 \times 10^{-11} \mathrm{M}\right)$. Therefore, the observed differences in folate binding by younger erythrocytes were due to true differences in the number of functional (in folate binding) FBPs and not due to significant differences in affinity. To determine if the observed decrease in folate binding was accompanied by a proportionate decrease in the amount of immunoreactive FBP in red cells separated on the basis of age, solubilized membranes obtained from age-separated cells were analyzed by the RIA to detect cross-reacting material to PFR. The results showed that each cohort of aging erythrocytes contained essentially similar amounts of cross-reacting material (Fig. 9). Pretreatment of erythrocyte membranes with low pH (5.5) and $\mathrm{pH} 8$ lysis buffer did not result in any change $(<5 \%$ variation) in the content of immunoreactive folate binding protein. When corrected for the number of cells, the data indicated 1,500 \pm 150 molecules of immunoreactive FBP per cell. Interestingly, Scatchard analysis of ligand binding data revealed $\sim 2$ molecules of functional FBP per cell in the cohort of reticulocyte-rich young cells. (Assuming a 1:1 molar stoichiometric ratio of ligand binding), these data indicated that (a) the observed folate binding was only to a fraction of the total immunoreactive FBP per cell; $(b)>99 \%$ of the immunoreactive protein was nonfunctional; $(c)$ ligand binding studies were 100-200-fold more sensitive than the RIA to detect small differences in functional FBP in young versus aged erythrocytes. The circulating erythrocyte FBP could be degraded shortly before (or after) its release from the bone marrow if it was functional in erythroid precursors; this was not investigated in bone marrow cells. Taken together, the ligand binding studies and the RIA support the hypothesis that with the onset of red cell aging there is a rapid decrease in the functional capacity of the erythrocyte FBP to bind folate that is not due to a concomitant loss of immunoreactive FBP. The use of high specific activity ${ }^{125} \mathrm{I}$-labeled PteGlu (histamine derivative) has nevertheless identified that aged red cells have much lower capacity to bind folate than younger cohorts.

\section{Discussion}

Using a highly purified, stable, novel folate analogue, the data on high affinity, specificity, saturability, $\mathrm{pH}$, time- and temperature-dependence of erythrocyte membranes as presented in this paper extends earlier observations (3) of shared antigenic determinants between the placental folate receptor and a moiety on intact erythrocytes. These specific folate binding moieties were solubilized out of erythrocyte membranes by non-ionic detergents where they eluted predominantly as $160,000 M_{\mathrm{r}}$ species. Anti-PFR antiserum also immunoprecipitated solubilized $160,000 M_{\mathrm{r}}$ iodinated membrane proteins. Evidence that this specific antibody interaction was with FBPs on erythrocyte membranes came from experiments where antiserum to PFR specifically immunoprecipitated ${ }^{125}$ I-labeled PteGlu (histamine derivative)-bound proteins in a dose-dependent manner. The data that support the possibility that these erythrocyte folate binding sites may be bound by folates present in serum was shown by experiments with "acid stripping" that uncovered cryptic folate binding sites.

The binding constants of erythrocyte membrane FBPs with various folate analogues were comparable to that reported earlier in particulate membranes from human placenta, milk, KB cells, leukemic cells, goat milk, rabbit and porcine choroid plexus, and rat kidney $(3,5-7,12,15,24-29)$. However, studies on folate uptake systems in several other intact mammalian cells including L-1210 cells (33-35), PHA stimulated lymphocytes (36), and human bone marrow cells (37) and human erythrocytes (10) suggest that transport was equally efficient and maximal for 5-methyltetrahydrofolate, 5-formyltetrahydrofolate and amethopterin, while that for PteGlu was poor. With the exception of L1210 cells, where the affinity of the transport system for folates correlates with affinity for folates by surface membrane FBPs (34), competitive binding inhibition studies (similar to that reported with P-FBPs) using crude membranes or purified folate binding proteins from these cells (lymphocytes, bone marrow cells, and erythrocytes) have not been reported. Therefore, it is not known if other unique folate transport proteins in these cells can bind and internalize various reduced folates more efficiently than PteGlu. Along these lines, we are currently investigating the basis for the apparent dichotomy between the high binding constants of erythrocyte FBPs for PteGlu and 5-methyltetrahydrofolate and the marked differences reported in the affinity of the transport system in intact human erythrocytes (10). It should nevertheless be pointed out that in our recent studies with human $\mathrm{KB}$ cells, membrane-associated FBPs bound PteGlu and 5-methyltetrahydrofolate with high affinity, and intracellular transport of both folates were comparable and mediated by these FBPs $(8,24,38)$. Kamen and Capdevila (39) have also recently demonstrated that similar FBPs on monkey kidney cells in culture specifically bind PteGlu and 5-methyltetrahydrofolate and transport the latter by a process that is consistent with 
receptor-mediated endocytosis. Thus, there appears to be no controversy regarding the relatively high binding constants of FBPs and FBP-mediated transport efficiencies for PteGlu and 5-methyltetrahydrofolate in human KB cells and monkey kidney cells when both parameters (binding and transport) were directly analyzed.

Recently, hemoglobin has been shown to possess a folate binding site (40). Evidence to rule out the possibility that the observed binding of folate to erythrocyte membranes was through hemoglobin, which contaminated the membrane preparations are as follows: (a) the dissociation constant of erythrocyte folate binding moieties for folate were more consistent with that of a high affinity, low capacity system in the nanomolar range, while folate binding to hemoglobin was more consistent with a lower affinity, high capacity system (micromolar range); (b) there was apparently no difference in ${ }^{125}$ I-labeled PteGlu (histamine derivative) binding to "pink" membranes (which contained 100-fold more hemoglobin) compared to "white" membranes; $(c)$ the specific immunoprecipitation of ${ }^{125} \mathrm{I}$-labeled PteGlu (histamine derivative) bound to solubilized erythrocyte folate binding proteins by antiplacental folate receptor serum; and $(d)$ the apparent molecular weight of the erythrocyte folate binding protein on gel filtration in detergent $\left(M_{\mathrm{r}} 160,000\right)$ compared to hemoglobin. The observations that intracellular folates dissociate from binding sites on hemoglobin at lower oxygen tension while binding was increased at higher oxygen tension (41) raised the possibility that the membrane-associated folate binding proteins may somehow participate in this process. However, preliminary studies on folate binding to lysed (white) membranes under low and high oxygen tension appear not to support an alteration in affinity for folate under these circumstances (unpublished observations).

Due to the heterogenous nature of the red cells with respect to age in a given sample of whole blood (ranging from 1 to 120 d), it was necessary to determine if the observed folate binding was predominantly to younger erythrocytes or reticulocytes. When separated on the basis of age, the reticulocyte-rich fractions in a Stractan density gradient had a 6.75-fold greater folate binding capacity compared to unfractionated cells that was not due to differences in affinity compared to aged cells. However, even older cells (containing no contaminating reticulocytes) possessed folate binding capacity. To determine if this apparent decrease in radioligand binding with erythrocyte aging was accompanied by parallel changes in immunoreactive FBP, cohorts of cells separated on the basis of age were analyzed by a RIA which measured cross-reacting material to placental folate receptors. The results indicated that the amount of immunoreactive FBP did not decrease with age. These findings suggested a progressive loss of functional FBP as erythrocytes aged. The amount of erythrocyte FBP per erythrocyte as estimated by RIA indicated $\sim 1,500$ immunoreactive FBP molecules per cell and constituted $0.016 \%$ of the total solubilized membrane protein. These studies also documented that this novel radioligand, the iodinated histamine derivative of folate, was at least two orders of magnitude more sensitive than the RIA in detecting small differences in the number of functional FBPs. Use of both assay methods (ligand binding to membranes and RIA on solubilized membrane proteins) has supported the hypothesis that with the onset of aging in the circulation, the erythrocyte rapidly loses its func- tional FBPs without a concomitant loss of the membrane FBP per se.

These findings are similar to that observed with the insulin receptor on erythrocytes that decrease in direct proportion to the red cell aging process (31). However, no direct studies of immunoreactive insulin receptor were reported to identify if there were similar findings as reported in our studies. The data presented for erythrocyte transferrin receptors is also different from our results. In that case (42) there is a proportionate and abrupt decrease in both transferrin binding and immunoreactive transferrin receptor when reticulocytes matured to erythrocytes. Since evaluation of transferrin receptor content was made on reticulocytes from patients with hemolytic anemias, (where the overall age of erythrocytes contaminating the reticulocytes would be younger), it is not known if the immunoreactive transferrin receptor is present in older erythrocytes as shown with FBPs. Nevertheless, immunofluorescent analysis of erythrocyte FBPs and transferrin receptors also showed major differences where FBPs were present in all red cells in varying degrees while transferrin receptors were only identified in reticulocytes. A discrepancy between the ligand binding studies and immunoreactive FBP has previously been observed with serum FBPs in normal individuals as well under various disease states (43). The significance of excess immunoreactive nonfunctional FBPs in serum is unclear; in erythrocyte membranes it may be a reflection of FBP degradation during the aging process.

The first indirect evidence for a receptor role for plasma membrane-associated folate binding moieties in vivo were performed by Zamierowski and Wagner (44) who showed that shortly after administration to rats, radiolabeled folate was first localized in liver cells on the external plasma membrane before its translocation intracellularly. McHugh and Cheng (12) subsequently confirmed folate binding to particulate membranes in cultured human $\mathrm{KB}$ cells. We have recently demonstrated a transport role for these particulate folate binding moieties in KB cells in the cellular uptake of 5-methyltetrahydrofolate (8). However, as shown by McHugh and Cheng (12) and confirmed by us (8), these FBPs may also be intracellular proteins that could function as folate storage proteins. The functional erythrocyte FBP is antigenically related to and appears to share most of the functional ligand binding characteristics as the 5-methyltetrahydrofolate transport proteins in KB cells (24). The striking difference however, is the quantitatively higher content of these P-FBPs in KB cells (12) and relatively minute quantities in erythrocyte membranes; the major difference being the folate requirement during the rapid growth rate of KB cells (which have a doubling time of $\sim 24 \mathrm{~h}$ ), while erythrocytes are nondividing cells that completed DNA synthesis and their requirement for folates at younger stages within the bone marrow. An issue raised by the identification of P-FBPs in mature human erythrocyte membranes is therefore related to the physiological role of these proteins. These cells contain predominantly polyglutamated forms of folate and yet do not contain the enzyme pteroyl polyglutamate synthetase, which is only present in immature red cells. This enzyme is responsible for the addition of the polyglutamate chain to 5-methyltetrahydrofolate taken up from serum. This implies that the existing folate in the mature cell was taken up at a more immature stage of erythrocyte development. This has been verified experimentally by earlier observations (and that 
presented in this paper) that more folate is taken up by younger erythrocyte forms (reticulocytes) than mature cells (9, 11). However, the fact that mature erythrocytes can take up 5-methyltetrahydrofolate (10) by a specific, saturable carriermediated process, and the clinical observations that the intraerythrocyte folate content is $\mathbf{3 0}$-fold higher than of serum (1), support the possibility that the erythrocyte has the capacity to concentrate folate against a gradient by a folate transport system. Whether specific folate transport in intact erythrocytes is mediated by FBPs is currently under study.

Without the availability of purified serum folate binding proteins, we cannot rule out the possibility that the observed functional and nonfunctional FBPs in erythrocyte membranes are due to adsorption of FBPs from the serum. Such a process could arise either through specific (binding) interactions or by hydrophobic or ionic interactions with erythrocyte membrane proteins. Investigation of membrane-associated FBPs and the folate transport system in this simplest of human cells may highlight their physiological expression in more complex human cells. Finally, tissues that have previously not been found to contain functional FBPs by ligand binding studies should be reevaluated using the higher specific activity folate analogue and the RIA described here to identify their distribution in normal and diseased states.

\section{Acknowledgments}

The expert secretarial assistance of Shirley Duke and Stephanie Moore and technical assistance of Asha Gupta and Joseph A. LaRosa in some of the experiments is gratefully acknowledged.

This work was supported by grants CA-36752 and HD-20889, awarded to Dr. Antony from the National Institutes of Health.

\section{References}

1. Beck, W. S. 1983. Metabolic aspects of vitamin $B_{12}$ and folic acid. In Hematology. W. J. Williams, E. Beutler, A. J. Erslev, R. W. Rundles, and M. A. Lichtman, editors. McGraw-Hill Book Co., New York. pp. 311-331.

2. Beck, W. S. 1985. Megaloblastic anemias. In Cecil Textbook of Medicine. J. B. Wyngaarden, L. H. Smith, Jr., editors. W. B. Saunders, Philadelphia. pp. 893-900.

3. Antony, A. C., C. S. Utley, K. C. Van Horne, and J. F. Kolhouse. 1981. Isolation and characterization of a folate receptor from human placenta. J. Biol. Chem. 256:9684-9692.

4. Munro, H. N., S. J. Pilistine, and M. E. Fant. 1983. The placenta in nutrition. Annu. Rev. Nutr. 3:97-124.

5. Wagner, C. 1982. Cellular folate binding proteins. Function and significance. Annu. Rev. Nutr. 2:229-248.

6. Waxman, S., C. Schreiber, and M. Rubinoff. 1978. The significance of folate binding proteins in folate metabolism. In Advances in Nutritional Research. H. Draper, editor. Plenum, NY. 55-76.

7. Colman, N., and V. Herbert. 1980. Folate binding proteins. Annu. Rev. Med. 31:433-439.

8. Antony, A. C., M. A. Kane, R. M. Portillo, P. C. Elwood, and J. F. Kolhouse. 1985. Studies of the role of a particulate folate-binding protein in the uptake of 5-methyltetrahydrofolate by cultured human KB cells. J. Biol. Chem. 260:14911-14917.

9. Izak, G., N. Rachmilewitz, K. Grossowicz, K. Galewski, and S. H. Kraus. 1968. Folate activity in reticulocytes and the incorporation of tritiated pteroyl-glutamic acid into red cells. Br. J. Haematol. 14:447-452.

10. Branda, R. F., B. K. Anthony, and H. S. Jacob. 1978. The mechanism of 5-methyltetrahydrofolate transport by human erythrocytes. J. Clin. Invest. 61:1270-1275.

11. Corcino, J. J., S. Waxman, and V. Herbert. 1971. Uptake of tritiated folates by human bone marrow cells in vitro. Br. J. Haematol. 20:503-510.

12. McHugh, M., and Y.-C. Cheng. 1979. Demonstration of a high affinity folate binder in human cell membranes and its characterization in cultured human KB cells. J. Biol. Chem. 254:11312-11318.

13. Hunter, W. M., and F. C. Greenwood. 1962. Preparation of ${ }^{131}$ I-labelled human growth hormone of high specific activity. Nature (Lond.). 194:495-496.

14. Lieber, M. R., and T. L. Steck. 1982. A description of the holes in human erythrocyte membrane ghosts. J. Biol. Chem. 257:1165111659.

15. Lowry, O. H., N. J. Rosebrough, A. L. Farr, and R. J. Randall. 1951. Protein measurement with the Folin phenol reagent. J. Biol. Chem. 193:265-275.

16. Eilers, R. J. 1967. Notification of final adoption of an international method and standard solution for hemoglobinometry specifications for preparation of standard solution. Am. J. Clin. Pathol. 47:212.

17. Steck, T. L., and J. A. Kant. 1974. Preparation of impermeable ghosts and inside-out vesicles from human erythrocyte membranes. Methods Enzymol. 31:172-180.

18. Antony, A. C., C. S. Utley, P. D. Marcell, and J. F. Kolhouse. 1982. Isolation, characterization, and comparison of the solubilized particulate and soluble folate binding proteins from human milk. $J$. Biol. Chem. 257:10081-10089.

19. Markwell, M. A. K., and C. F. Fox. 1978. Surface-specific iodination of membrane proteins of viruses and eukaryotic cells using 1,3,4,6-tetrachloro-3 $\alpha, 6 \alpha$-diphenylglycouril. Biochemistry. 17:48074817.

20. Corash, M. L., S. Piomelli, H. C. Chen, C. Seaman, and E. Cross. 1974. Separation of erythrocytes according to age on a simplified density gradient. J. Lab. Clin. Med. 84:147-151.

21. Beutler, E. 1971. Puruvate kinase. In Red Cell Metabolism. Grune \& Stratton, Inc., New York. pp. 50-58.

22. Atwater, J., and A. J. Erslev. 1983. Reticulocyte staining. In Hematology. W. J. Williams, E. Beutler, A. J. Erslev, R. W. Rundles, and M. A. Lichtman, editors. McGraw Hill Book Co., New York. pp. 1604-1605.

23. Wang, C., and R. L. Smith. 1975. Lowry determination of proteins in the presence of Triton X-100. Anal. Biochem. 63:414-417.

24. Kane, M. A., A. C. Antony, and J. F. Kolhouse. 1984. Folic acid and $\mathrm{N}^{5}$-methyltetrahydrofolate share a common membrane-associated binding protein in human KB cells. Blood. 64:69a. (Abstr.)

25. Rothenberg, S. P., and M. DaCosta. 1971. Further observations on the folate binding factor in some leukemic cells. J. Clin. Invest. 50:719-726.

26. Rubinoff, M., C. Schreiber, and S. Waxman. 1975. Isolation and characterization of folate binding protein (FABP) from goat milk by affinity chromatography. FEBS. (Fed. Eur. Biochem. Soc.) Lett. 75:244-248.

27. Spector, R. 1977. Identification of folate binding macromolecule in rabbit choroid plexus. J. Biol. Chem. 252:3364-3370.

28. Selhub, J., and W. A. Franklin. 1984. The folate-binding protein of rat kidney: purification, properties and cellular distribution. $J$. Biol. Chem. 259:6601-6606.

29. Sulieman, S. A., and R. Spector. 1981. Purification and characterization of a folate binding protein from porcine choroid plexus. Arch. Biochem. Biophys. 208:87-94.

30. Elwood, P. C., M. A. Kane, R. M. Portillo, and J. F. Kolhouse. 1986. The isolation, characterization and comparison of the membrane-associated and soluble folate-binding proteins from human KB cells. J. Biol. Chem. 261:15416-15423.

31. Dons, F. R., M. L. Corash, and P. Gorden. 1981. The insulin receptor is an age-dependent integral component of the human erythrocyte membrane. J. Biol. Chem. 256:2982-2987. 
32. Scatchard, G. 1949. The attractions of proteins for small molecules and ions. Ann. NY Acad. Sci. 51:660-672.

33. Huennekens, F. M., K. S. Vitols, and G. B. Henderson. 1978. Transport of folate compounds in bacterial and mammalian cells. $A d v$. Enzymol. Relat. Areas Mol. Biol. 47:313-346.

34. Henderson, G. B., B. Grzelakowska-Sztabert, E. M. Zevely, and F. M. Huennekens. 1980. Binding properties of the 5-methyltetrahydrofolate/methotrexate transport system in L1210 cells. Arch. Biochem. Biophys. 202:144-149.

35. Huennekens, F. M., M. R. Suresh, C. E. Grimshaw, D. W. Jacobsen, E. T. Quadros, K. S. Vitols, and G. B. Henderson. 1983. Transport of folate and pterin compounds. In Chemistry and Biology of Pteridinies. P. A. Blair, editor. Walter de Gruyter. NY. pp. 1-22.

36. Das, K. C., and A. V. Hoffbrand. 1970. Studies of folate uptake by phytohemagglutinin-stimulated lymphocytes. Br. J. Haematol. 19:203-221.

37. Hoffbrand, A. V., E. Tripp, D. Catovsky, and K. C. Das. 1973. Transport of methotrexate into normal hematopoietic cells and into leukemia cells and its effects on DNA synthesis. Br. J. Haematol. 25:497-511.
38. Antony, A. C., M. A. Kane, and J. F. Kolhouse. 1983. Characterization of a membrane protein involved in folate uptake by malignant human cells. Blood. 62:42a. (Abstr.)

39. Kamen, B. A., and A. Capdevila. 1986. Receptor-mediated folate accumulation is regulated by the cellular folate content. Proc. Natl. Acad. Sci. USA. 83:5983-5987.

40. Benesch, R. E., S. Kwong, R. Benesch, and C. Baugh. 1985. The binding of folyl- and anti-folylpolyglutamates to hemoglobin. J. Biol. Chem. 260:14653-14658.

41. Nelson, N. L., J. S. Klausher, and R. F. Branda. 1983. Oxygen alters red cell folate levels. Br. J. Haematol. 55:235-242.

42. Frazier, J. L., J. H. Caskey, M. Yoffe, and P. A. Seligman. 1982. Studies of the transferrin receptor on both reticulocytes and nucleated human cells in culture. Comparison of factors regulating receptor density. J. Clin. Invest. 69:853-865.

43. DaCosta, M., S. P. Rothenberg, C. Fischer, and Z. Rosenberg. 1981. The identification and measurement of a folate-binding protein in human serum by radioimmunoassay. J. Lab. Clin. Med. 91:901910.

44. Zamierowski, M. M., and C. Wagner. 1977. Identification of folate binding proteins in rat liver. J. Biol. Chem. 252:933-938. 